\title{
Non-Conventional Mineral Binder-Bonded Lignocellulosic Composite Materials: A Review
}

\author{
Opara Uchechukwu Emmanuel, ${ }^{\text {a,b }}$ Aldi Kuqo, ${ }^{\mathrm{a}}$ and Carsten Mai ${ }^{\mathrm{a}, *}$ \\ The construction industry suffers from unsustainability and contributes \\ more than any other industrial sector to carbon emissions that lead to \\ global warming. Increasing economic and environmental concerns related \\ to conventional energy- and $\mathrm{CO}_{2}$-intensive building materials have \\ propelled the rapid and sustained expansion of research in the area of \\ plant-based inorganic mineral binder-bonded materials for the \\ construction industry. The resulting composites can be qualified as eco- \\ responsible, sustainable, and efficient multifunctional building materials. \\ So far, most of these research efforts have not received as much attention \\ as materials based on ordinary Portland cement (OPC). To address this \\ gap, this review focuses on mineral binder-based lignocellulosic \\ composites made from non-conventional inorganic mineral binders/ \\ cements with low embodied energy and low carbon footprint, namely \\ hydrated lime-based binders, magnesium-based cement, alkali-activated \\ cement, and geopolymers, as sustainable alternatives to OPC-bonded \\ lignocellulosic composites (state-of-the-art). The emphasis here is on the \\ application potentials, the influence of production parameters on the \\ material properties/ performance, and recent advancement in this field. \\ Finally, a prediction is provided of future trends for these non-conventional \\ mineral binder-bonded lignocellulosic composites.
}

Keywords: Non-conventional mineral binders; Inorganic bonded composites; Sustainable construction; Natural fibers; Bio-based materials

Contact information: a: Wood Biology and Wood Products, Faculty of Forest Sciences and Forest Ecology, University of Goettingen, Büsgenweg 4, 37077 Göttingen, Germany; b: Department of Forestry and Wood Technology, Federal University of Technology Akure, PMB 704, Akure, Ondo State, Nigeria;

* Corresponding author: cmai@gwdg.de

\section{INTRODUCTION}

Lignocellulosic composites are engineered products manufactured from wood or other lignocellulosic raw materials, together with a suitable matrix/binder. Depending on the nature of the matrix, they are classified as organic matrix composites such as particleboards, fiberboards, and oriented strand boards (OSB) as well as inorganic mineral matrix composites such as those made from ordinary Portland cement (OPC), gypsum, and magnesia, which have been widely used in the manufacture of reinforced panels and structures in construction. Organic matrix-bonded composites are usually processed, depending on the raw materials, specific design, and end-use, by spray/hand lay-up under heat and pressure application, resin transfer molding, etc. They can also be processed by extrusion, compression molding, and injection molding as used for wood-plastic composites (WPC) (Nagavally 2016; Rajak et al. 2019). The focus of this study, however, is on inorganic mineral binder-bonded composites for construction applications; these are products containing lignocellulosic materials fully encapsulated in a continuous inorganic matrix. Inorganic-bonded composites are generally processed at ambient temperature by 
casting, compact casting, and pressure (Irle et al. 2013; Stark et al. 2010), although, in some cases, additional heat may be applied to aid curing.

The most common inorganic-bonded composites incorporate gypsum, ordinary Portland cement (OPC), and magnesia cement as the matrix. Gypsum- and magnesiabonded composites are mostly restricted to interior applications due to their moisture sensitivity, while the more durable OPC composites are used in both interior and exterior applications. The growing interest and adoption of lignocellulosic materials to manufacture mineral binder-bonded composites for construction applications are mainly triggered, among other advantageous properties, by their wide geographical distribution and ease of handling/processing (Mohammed et al. 2015). The matrix/binder system adopted to produce inorganic mineral binder-bonded composites, however, has far-reaching impacts on the properties, performance, and environmental profile (Shalbafan et al. 2020).

Generally, the construction industry is not sustainable, owing to the high consumption of materials with high energy content and associated $\mathrm{CO}_{2}$ emissions (Murphy et al. 2010; Ghavami et al. 2017). In a bid to reduce such negative impacts, scientists are challenged to develop more innovative customized, environmentally sound, nonconventional materials for indoor and outdoor use. Over the years, considerable efforts have been made in the development and application of novel inorganic mineral binder systems that show remarkable potential for producing alternative multifunctional engineered materials for construction applications (Walker and Pavía 2014; Sarmin et al. 2014; Miller et al. 2017; Soltan et al. 2017; Kang et al. 2019). These materials must feature sustainability characteristics that are superior to existing conventional materials, while retaining the main advantages of mineral binder-bonded materials in terms of higher mechanical properties, toughness, fire resistance, and durability against environmental influences and biodeterioration agents (Shalbafan et al. 2016; Bahrami et al. 2019; Shalbafan and Thoemen 2020). Non-conventional mineral binder-bonded lignocellulosic composites have increasingly emerged as an important class of alternative construction materials. They are obtained by combining the functional properties of the mineral binders with the advantages of lignocellulosic materials to give customized products of enhanced thermal stability, moisture preclusion, and improved mechanical performance. These products can meet the critical requirements of low carbon footprint and sustainability as well (Sarmin et al. 2014; Shalbafan et al. 2016; Moslemi and Begum 2017; Jin et al. 2017; Shalbafan et al. 2020). Additionally, non-conventional mineral binder-bonded lignocellulosic composites have the advantage of being able to utilize a wide range of organic and inorganic raw materials, including the valorization of agricultural residues and industrial wastes. The resulting products not only equal the conventional materials from OPC in terms of performance and cost-effectiveness, but they are also ecologically responsible.

Research related to the production of composites using inorganic mineral binders is in rapid flux. A majority of the reviews on this topic have focused primarily on Portland cement-bonded lignocellulosic composites, as these are the most widely used class of lowcost inorganic bonded composites (Frybort et al. 2008; Kang et al. 2019). Recently, however, other types of inorganic mineral binder materials have been increasingly studied. Some of these are of ecological importance and exhibit less embodied energy. Therefore, this study reviews the developments in the use of these rather lesser-described binders for mineral binder-bonded lignocellulosic composite technologies.

This study is structured in two major sections: the first section discusses mineral binder-bonded lignocellulosic composites based on hydrated lime binders, magnesium- 
based cement, and alkali-activated and geopolymer binders, focusing on their application potentials, the influence of production parameters on their properties/performance, as well as recent advancement. Another section provides a conclusion and description of the future trends for non-conventional mineral binder-bonded lignocellulosic composites.

\section{LIME-BASED LIGNOCELLULOSIC COMPOSITES}

Lime is a calcium-rich inorganic mineral composed primarily of oxides and hydroxide, with several applications in construction, environmental protection, industrial and agricultural processes. Generally, lime is obtained by burning limestone $\left(\mathrm{CaCO}_{3}\right)$ at temperatures above $900{ }^{\circ} \mathrm{C}$ to produce highly caustic quicklime $(\mathrm{CaO})$, with a corresponding release of $\mathrm{CO}_{2}$ (Eq. 1). The quicklime $(\mathrm{CaO})$ is subsequently slaked with water to produce hydrated lime or air lime $\left(\mathrm{Ca}(\mathrm{OH})_{2}\right)$ (Eq. 2) (Kang et al. 2019). Lime can also be recovered as a by-product from sugar refineries (lime sludge), welding (calcium carbide sludge), acetylene, and paper industries, where lime materials are used as chemical feedstocks. Lime-based materials can partially replace and/or substitute high embodied energy materials for certain applications in construction. This increases the overall ecologically friendly nature of the products by reducing or eliminating $\mathrm{CO}_{2}$ emissions generated during the production of buildings and building material, mostly associated with the consumption of ordinary Portland cement (OPC) (Walker et al. 2014).

$$
\begin{aligned}
& \left.\mathrm{CaCO}_{3} \text { (calcination at } \sim 900{ }^{\circ} \mathrm{C}\right) \rightarrow \mathrm{CaO}+\mathrm{CO}_{2} \\
& \mathrm{CaO}+\mathrm{H}_{2} \mathrm{O} \rightarrow \mathrm{Ca}(\mathrm{OH})_{2}
\end{aligned}
$$

In itself, pure hydrated lime $\left(\mathrm{Ca}(\mathrm{OH})_{2}\right)$ or air lime is a common non-hydraulic binder whose hardening depends on a process called carbonation (i.e., reaction with $\mathrm{CO}_{2}$ from the air) to produce calcium carbonate. In construction applications, however, limes are rarely used alone as the main cementitious binder but rather in combination with reactive additives (clay or pozzolana) to form a hydraulic cement. These exhibit better binding efficiency, shorter setting time, and enhanced strength properties, while retaining the sufficient durability characteristic of lime materials. This type of hydraulic cement can be used alone or as a partial substitute for OPC in non-performance secondary applications such as masonry, plastering, and production of composites for walling and insulation (Billong et al. 2011; Fic et al. 2013; Brzyski et al. 2017; Page et al. 2017).

\section{Lime-Lignocellulosic Composites, Performance}

While lime has been a construction material since antiquity (Carran et al. 2012; Veiga 2017; Shao et al. 2018), its use in modern construction was curtailed with the introduction of OPC in the $19^{\text {th }}$ century, which possesses better strength and other performance properties at relatively lower cost (Kang et al. 2019). However, increasing demand for low-energy, carbon-negative, and sustainable building materials has reignited interest in the development of lime-based construction materials of improved properties using bio-aggregates (Cizer et al. 2010; Billong et al. 2011; Walker et al. 2011; Lorca et al. 2014; Pavlík and Užáková 2016; Payá et al. 2017; Kang et al. 2019; Abdellatef et al. 2020). 


\section{Acoustic, thermal, and hygrothermal properties}

Lime-lignocellulosic composites have been well studied in terms of their acoustic, thermal, and hygrothermal properties (i.e., movement of heat and moisture). One of such materials is the lime-hemp concrete or "Hempcrete", which was developed in the late 1980s/early 1990s in France as a sustainable alternative material for the restoration of historic buildings and to lessen the weight of ordinary Portland cement (OPC) concrete (Dai et al. 2010; Walker et al. 2014). It consists mainly of hemp shives (Kurd), the woody core of the hemp stalk after fibers have been extracted, and a lime-based binder. Other additives such as pozzolans, natural hydraulic lime, and a certain percentage of OPC may be included to enhance the binder properties such as reduced setting times, improved binder efficiency, and mechanical performance (Pochwała et al. 2020). Lime-hemp concrete exhibits excellent acoustic, thermal and hygrothermal properties as well as moisture transport qualities. These are mainly due to the highly porous structure (macropores) of the hemp shives, which allow it to absorb an enormous amount of water, and show good transpirability (Glé et al. 2011; Arizzi et al. 2015). Consequently, the highly porous lightweight composite displays higher thermal capacity, lower thermal conductivity, and higher water vapor permeability with the ability to buffer moisture and temperature changes better than OPC concrete (Evrard and De Herde 2010; Walker and Pavía 2014; Kinnane et al. 2015; Abdellatef et al. 2020). Accordingly, Hempcrete is increasingly being used in parts of Europe and Canada as a sustainable envelope material for wall cladding, exterior coatings, floor tiling, and insulation of ceiling and roof (Murphy et al. 2010; Page et al. 2017; Pochwała et al. 2020).

Increasing the flax fiber content and the addition of a foaming agent lowered the thermal conductivity $(\lambda)$ of flax-lime materials to the range of 0.13 to $0.14 \mathrm{~W} / \mathrm{m} \mathrm{K}$ and $0.20 \mathrm{~W} / \mathrm{m} \mathrm{K}$, respectively, thereby resulting in a low-density material (Fic et al. 2013). Rahim et al. (2015) investigated the moisture-related properties (sorption isotherm and water vapor permeability) and moisture buffer values (MBV) of flax-lime concrete, in comparison to hemp-lime concrete. They found that the flax-lime concrete exhibit high hygric performance as well as a moisture buffer capacity equal to that of the hemp-lime material, with MBV values of $2.02 \mathrm{~g} /\left(\mathrm{m}^{2} \% \mathrm{RH}\right)$ and $2.27 \mathrm{~g} /\left(\mathrm{m}^{2} \% \mathrm{RH}\right)$ for hemp and flax concretes, respectively. These findings demonstrate that flax materials, when combined with a lime-based binder, can be upcycled into a sustainable green "flax-lime concrete" with potential functional applications in buildings. The capillary water absorption of hybrid hemp-flax lime-based concrete with a 9:1 hemp shive to flax fiber ratio was determined more by the overall aggregates/binder ratio, which is influenced by the complex porosity and increased tortuosity of the capillary networks, than by the water absorption capacity of the individual fibers. At the same time, the thermal insulation properties remained within acceptable limits (Page et al. 2017).

Belakroum et al. (2018) studied the thermal and acoustic properties of lime-date palm fiber composites. At a fiber volume range of 20 to $50 \%$, the thermal conductivity ranged from 0.21 to $0.091 \mathrm{~W} / \mathrm{m} \mathrm{K}$ and sound absorption capacities in medium and high frequencies were enhanced. Moisture buffering was also higher in these variants than in those with fewer fibers. The use of various particle dimensions in lime-OPC-wood particle composites resulted in different densities and thermal conductivity values of the composites (Park et al. 2019). Thermal conductivity ranged from 0.0742 to $0.1078 \mathrm{~W} / \mathrm{m} \mathrm{K}$ for big and small particles, respectively. Furthermore, wood-lime boards with larger particles had lower moisture content at $60 \%$ relative humidity $(\mathrm{RH})$ but higher moisture 
content at $70 \% \mathrm{RH}$, implying that for relatively low $\mathrm{RH}$, wood-lime boards with larger particles are more suitable as building materials.

\section{Mechanical properties}

Table 1 shows the production parameters and strength properties of various limebased lignocellulosic composites. Hempcrete is typically applied as a "light work" nonstructural building skin, cast around load-bearing structural frames in the construction and thermal upgrading of buildings (Walker and Pavía 2014). Substantial initial compressive strength development of the Hempcrete at the time of application is important to support its wet weight, which is more than twice its dry weight (Hirst et al. 2010; Murphy et al. 2010; Walker and Pavía 2010).

Owing to the rough surface, flax fibers exhibited very good adhesion with the lime matrices, resulting in a ductile composite material (Fic et al. 2013). Compressive strength ranged from 0.45 to $0.65 \mathrm{MPa}$, as a function of the material bulk density. The lowest strength and bulk density were observed in materials in which a foaming agent was applied due to high corresponding porosity. Hydrophobization of flax straw by impregnation with flaxseed oil resulted in an accelerated binding process of the lime matrix with improved mechanical properties. The exact mechanisms, however, by which this effect of the accelerated binding process occurs in the presence of flax oil need to be further elucidated. The incorporation of flax fibers to a hybrid hemp-flax lime-based composite with a hempshive-to-flax-fiber ratio of 9:1 significantly enhanced the compressive strength, compactness, and ductility of the material with a corresponding reduction in shrinkage (Page et al. 2017).

Sunflower piths, due to their morphological similarities with hemp shives, were investigated in terms of their geometrical features related to the casting technique (Nozahic et al. (2012). The hemp and sunflower materials showed large similarities in terms of the mechanical properties of the resulting concrete. As the stalk is a sunflower by-product, which is available in large quantities, it is therefore a possible alternative to hemp shives for use in plant concrete. Unlike most lignocellulosic fiber composites, where the interface between the aggregates and the binder is the weakest point of the system, in lime-sunflower piths composites it is mainly the binder that provides the mechanical performance.

Three batches of relatively large fibers of giant reed (Arundo donax) with a length of 4,8 , and $12 \mathrm{~cm}$ were incorporated into a hydraulic lime mortar matrix to produce composites with a target application as ductile prefabricated bricks (Badagliacco et al. 2020). The addition of fibers led to a significant increase of the post-fracture flexural toughness compared to unreinforced mortars, but slightly reduced compressive strength. Of the three fiber batches, the medium variant $(8 \mathrm{~cm})$ had the greatest effect on strength. The extraordinarily high growth rate (similar to bamboo) and capability to produce huge amounts of biomass make giant reed (Arundo donax) an interesting candidate for application in composite production.

Di Bella et al. (2014) compared the effect of two types of natural fibers, namely sisal (Agave sisalana) and kenaf (Hibiscus cannabinus), and synthetic polypropylene fibers on the mechanical and durability properties (freeze/thaw and salt spray test) of the resulting lime plasters. The lime plasters reinforced with natural fibers resisted cracking and exhibited mechanical properties as well as freeze/thaw resistance comparable to that of plasters with polypropylene fibers. They exhibited higher resistance to degradation after aging time in the salt spray environment, with lower weight loss (14\%) after exposure compared to those with polypropylene (18\%). The resistance was attributed to the 
hydrophilic nature of the natural fibers, which enables them to partially absorb water from the salt solution and thus preserving the plaster (Di Bella et al. 2014). Thus, sisal and kenaf fibers can serve as suitable alternatives to polypropylene fibers in lime plaster applications.

Table 1. Overview of Lime-based Lignocellulosic Composites

\begin{tabular}{|c|c|c|c|c|c|c|c|}
\hline $\begin{array}{l}\text { Type of } \\
\text { fibers }\end{array}$ & $\begin{array}{c}\text { Amount } \\
\text { of fibers } \\
(\%)\end{array}$ & $\begin{array}{l}\text { Length } \\
\text { of } \\
\text { fibers } \\
\text { (mm) }\end{array}$ & $\begin{array}{l}\text { Type of } \\
\text { casting }\end{array}$ & $\begin{array}{l}\text { Density } \\
\left(\mathrm{kg} / \mathrm{m}^{3}\right)\end{array}$ & Fillers & $\begin{array}{c}\text { Maximal } \\
\text { strength of } \\
\text { composites } \\
\text { reinforced } \\
\text { with fibers } \\
(\mathrm{MPa})^{*} \\
\end{array}$ & Reference \\
\hline \multirow{4}{*}{$\begin{array}{l}\text { Hemp } \\
\text { shives }\end{array}$} & $\mathrm{n} / \mathrm{a}$ & $\mathrm{n} / \mathrm{a}$ & Casting & $\begin{array}{c}308.3 \text { to } \\
357.8\end{array}$ & $\mathrm{n} / \mathrm{a}$ & $\mathrm{n} / \mathrm{a}$ & $\begin{array}{c}\text { Pochwała et } \\
\text { al. (2020) }\end{array}$ \\
\hline & $\begin{array}{c}10-75 \\
(w t \%)\end{array}$ & $\mathrm{n} / \mathrm{a}$ & Casting & $\mathrm{n} / \mathrm{a}$ & $\mathrm{n} / \mathrm{a}$ & $\begin{array}{l}\text { FI: } 4 \mathrm{MPa} \text { for } \\
\text { 50\% fiber, } \\
\\
\text { CM: } \sim 17 \mathrm{MPa}\end{array}$ & $\begin{array}{c}\text { Murphy et al. } \\
(2010)\end{array}$ \\
\hline & $\mathrm{n} / \mathrm{a}$ & $\mathrm{n} / \mathrm{a}$ & Casting & $\begin{array}{c}265.8 \text { to } \\
461.2\end{array}$ & $\begin{array}{l}\text { Metakaolin } \\
\text { and OPC }\end{array}$ & $\mathrm{n} / \mathrm{a}$ & $\begin{array}{c}\text { Barnat- } \\
\text { Hunek et al. } \\
(2015)\end{array}$ \\
\hline & $\begin{array}{c}20-22 \\
(w t \%)\end{array}$ & $\mathrm{n} / \mathrm{a}$ & $\begin{array}{c}\text { Casting } \\
\text { d- } \\
100 \mathrm{~mm} \text {, } \\
\text { h-200 } \\
\mathrm{mm}\end{array}$ & $\begin{array}{c}290 \text { to } \\
350\end{array}$ & $\begin{array}{l}\text { Metakaolin } \\
\text { and crushed } \\
\text { bricks }\end{array}$ & $\begin{array}{c}\text { CM: } 0.47 \\
\text { MPa for } 22 \% \\
\text { fiber }\end{array}$ & $\begin{array}{c}\text { Abdellatef et } \\
\text { al. (2020) }\end{array}$ \\
\hline Flax fibers & $\mathrm{n} / \mathrm{a}$ & $\mathrm{n} / \mathrm{a}$ & $\begin{array}{c}\text { Casting, } \\
50 \times 50 \times \\
50 \mathrm{~mm}^{3} \\
\text { and } 100 \\
\times 100 \times \\
100 \mathrm{~mm}^{3} \\
\end{array}$ & $\begin{array}{c}250 \text { to } \\
500\end{array}$ & $\begin{array}{c}\text { Hemp } \\
\text { fibers/shives }\end{array}$ & $\begin{array}{c}\text { CM: } 0.25 \\
\text { MPa }\end{array}$ & $\begin{array}{l}\text { Page et al. } \\
(2017)\end{array}$ \\
\hline Flax fibers & $\mathrm{n} / \mathrm{a}$ & $\begin{array}{c}10 \text { to } 20 \\
\mathrm{~mm}\end{array}$ & $\begin{array}{c}\text { Casting, } \\
10 \times 10 \times 1 \\
0 \mathrm{~mm}^{3} \\
\end{array}$ & $\begin{array}{c}440 \text { to } \\
1290\end{array}$ & $\begin{array}{l}\text { Microsilica, } \\
\text { OPC }\end{array}$ & $\begin{array}{c}\text { CM: } 0.65 \\
\mathrm{MPa}\end{array}$ & $\begin{array}{c}\text { Fic et al. } \\
(2013)\end{array}$ \\
\hline $\begin{array}{l}\text { Sisal } \\
\text { fibers }\end{array}$ & $\begin{array}{c}0.2 \\
(w t \%)\end{array}$ & $5 \mathrm{~mm}$ & Casting & $\mathrm{n} / \mathrm{a}$ & $\begin{array}{l}\text { Poly- } \\
\text { propylene } \\
\text { fibres }\end{array}$ & $\begin{array}{c}\text { FI: } 0.39 \mathrm{MPa} \\
\begin{array}{c}\text { CM: } 0.39 \\
\mathrm{MPa}\end{array}\end{array}$ & $\begin{array}{l}\text { Di Bella et } \\
\text { al. (2014) }\end{array}$ \\
\hline $\begin{array}{l}\text { Kenaf } \\
\text { fibers }\end{array}$ & $\begin{array}{c}0.2 \\
(w t \%)\end{array}$ & $5 \mathrm{~mm}$ & Casting & $\mathrm{n} / \mathrm{a}$ & $\begin{array}{l}\text { Poly- } \\
\text { propylene } \\
\text { fibres }\end{array}$ & $\begin{array}{c}\text { FI: } 0.30 \mathrm{MPa} \\
\begin{array}{c}\text { CM: } 0.33 \\
\mathrm{MPa}\end{array}\end{array}$ & $\begin{array}{l}\text { Di Bella et } \\
\text { al. (2014) }\end{array}$ \\
\hline $\begin{array}{l}\text { Palm } \\
\text { fibers }\end{array}$ & $\begin{array}{c}20 \text { to } 50 \\
\text { (wt\%) }\end{array}$ & $\begin{array}{c}0.063 \text { to } \\
5\end{array}$ & $\begin{array}{l}\text { Casting, } \\
\text { d-80 } \\
\text { mm, h- } \\
160 \mathrm{~mm}\end{array}$ & $\begin{array}{c}680 \text { to } \\
950\end{array}$ & $\mathrm{n} / \mathrm{a}$ & $\begin{array}{l}\text { CM: } 0.6 \mathrm{MPa} \\
\text { for } 20 \% \text { fiber }\end{array}$ & $\begin{array}{l}\text { Belakroum } \\
\text { et al. (2018) }\end{array}$ \\
\hline $\begin{array}{l}\text { Giant reed } \\
\text { fibers }\end{array}$ & $\begin{array}{c}0.5 \text { to } 2 \\
\text { (wt\%) }\end{array}$ & $\begin{array}{c}40 \text { to } \\
120\end{array}$ & $\begin{array}{l}\text { Casting, } \\
40 \times 40 \times \\
160 \mathrm{~mm}^{3}\end{array}$ & $\begin{array}{c}1788 \text { to } \\
1875\end{array}$ & $\mathrm{n} / \mathrm{a}$ & $\begin{array}{l}\text { CM: } 7.51 \\
\text { MPa for } 1 \% \\
\text { fiber }\end{array}$ & $\begin{array}{l}\text { Badagliacco } \\
\text { et al. (2020) }\end{array}$ \\
\hline $\begin{array}{c}\text { Wood } \\
\text { particles }\end{array}$ & $\begin{array}{c}16.7 \\
(w t \%)\end{array}$ & $\begin{array}{c}0 \text { to } 1 \\
\text { and } \\
2.36 \text { to } \\
4.75\end{array}$ & $\begin{array}{c}\text { Casting, } \\
100 \\
\times 100 \times \\
20 \mathrm{~mm}^{3} \\
\end{array}$ & $\begin{array}{c}875 \text { to } \\
984\end{array}$ & OPC & $\mathrm{n} / \mathrm{a}$ & $\begin{array}{l}\text { Park et al. } \\
\text { (2019) }\end{array}$ \\
\hline $\begin{array}{c}\text { Sunflower } \\
\text { pith } \\
\text { particles }\end{array}$ & $\begin{array}{c}5.3 \\
(w t \%)\end{array}$ & 10 to 30 & $\begin{array}{c}\text { Compres } \\
\text { sion } \\
\text { casting, } \\
40 \times 40 \times \\
40 \mathrm{~mm}^{3}\end{array}$ & $\begin{array}{c}1084 \text { to } \\
1310\end{array}$ & Pumice sand & $\begin{array}{c}\text { CM: } 4.52 \\
\text { MPa for } 5.3 \% \\
\text { fiber }\end{array}$ & $\begin{array}{l}\text { Nozahic et } \\
\text { al. (2012) }\end{array}$ \\
\hline
\end{tabular}




\section{Influence of Production Parameters on the Strength Properties of Lime Composites}

A well-known property of hydrated-lime is that it can be easily combined with a wide range of natural and synthetic additives to yield materials of improved properties (Walker and Pavía 2010; Payá et al. 2017; Martínez-García et al. 2019). Various studies have investigated the influence of binder composition and hydraulicity on the mechanical strength of lime-hemp composites and stiffness (Murphy et al. 2010). Hirst et al. (2010) reported that strength properties of Hempcrete are not prominently dependent on the individual strength of the binder, but are rather a function of a complex interaction between the hemp and lime, influenced by mixing, density, and age.

\section{Hydraulicity of lime}

A more hydraulic lime binder resulted in a higher rate of mechanical strength gain and ultimate compressive strengths than pure hydrated lime relying solely on carbonation for strength development. The hydraulic additions in the commercial binder induce a partial hydraulic set, which is a faster process (Murphy et al. 2010). However, the influence of the lime binder hydraulicity on strength development, both in flexion and compression, decreased with increasing hemp content, particularly in compressive strength. On the other hand, the flexural strength of the materials was more influenced by the density of the composites compared to compression strength. Increasing binder hydraulicity induced by hydraulic lime and Portland cement improved the initial (24 h to 5 days) strength development and durability of the Hempcrete materials but did not significantly affect their ultimate strength after one year (Walker et al. 2014). Other authors have also reported advancement in the use of various agricultural wastes/residues as pozzolanic additives to improve the hydraulic properties, binding efficiency, and ecological profile of hydrated lime-based binders for construction purposes (Billong et al. 2011; Payá et al. 2017; Nayaka et al. 2018; Martínez-García et al. 2019).

\section{Casting technique}

In addition to the use of pozzolanic and hydraulic binder additive blends in formulated lime binders for lime-lignocellulosic composite production, the casting technique is another production parameter with a critical influence on the performance properties of the materials. Various molding techniques have been employed depending on the geometry, dimensions, and volume of fibers added in the lime paste.

Casting with a subsequent vibration process to eliminate the volume of pores, and hence, the porosity of the final product is a conventional casting technique to produce mineral binder-bonded lignocellulosic composites with a low volume of incorporated fibers mixed in a highly workable paste. The major objective is to achieve homogenous dispersion, adequate bonding, and sufficient interconnection between the aggregate and the matrix and, as a consequence, better mechanical performance of the composite. Casting by compaction (Fig. 1) is usually utilized for higher ratios of lignocellulosic aggregate/binder. Metal molds equipped with a movable bar are compressed by an external force compacting the binder-aggregate mixture until a specific thickness is achieved.

Nozahic et al. (2012) concluded that casting by compaction shows the high capability of the plant aggregate to be reorganized in layers and then to form concrete with orthotropic mechanical behavior. This was found to be an interesting way to greatly increase the compressive strength without increasing the density of the material in the same proportion, as it results in orthotropic properties. Indeed, the effectiveness of this technique 
is determined by the shape of the plant particle, because long and flat objects have the ability to be reorganized into layers during compaction.

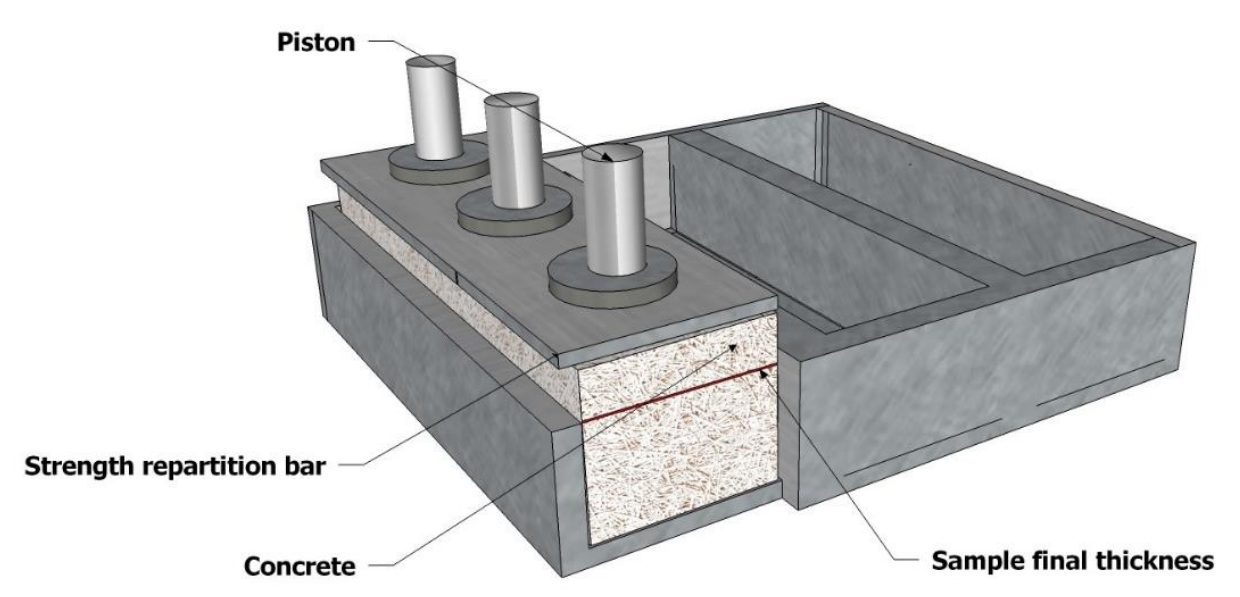

Fig. 1. Schematic diagram illustrating the compaction casting technique

The influence of the casting technique has also been investigated in terms of reducing the long setting and drying times of lime-based composites. This in turn shortens the labor time on site, reduces costs, and improves the initial hydraulic set of the concrete. A study investigated the influence of a projection casting process (Fig. 2) varied at distances from $0.5 \mathrm{~m}$ to $3.0 \mathrm{~m}$ on the mechanical (flexural strength, compression strength, and hardness) and thermal properties of Hempcrete.

Projection casting is a recently developed process in which a mixture of lime, shives, and water is projected either directly onto a wall formwork or into a block mold (Elfordy et al. 2008). Initially, a dry premix of lime and shives is conducted through a hose by air, and pressurized water is added just before the hose outlet. The projection process was adopted to minimize the time for the hemp component to absorb significant amounts of water, on the one hand, and to limit the total setting time to that required for lime carbonation, on the other, while achieving better compaction and higher density. A significant increase in the mechanical properties of the Hempcrete material was observed with increasing mortar density as a function of the projection distance. However, highest strength was achieved at a 1-m-projection distance, and a moderate density variation occurred within a given projected block, both along the length and across the width. This observation is comparable to the classical spray coating processes, where too short distances result in "splashing" of the projected material on the substrate. This leads to a poor stacking of the deposited particles. On the other hand, when the projection distance increases and becomes too long, the kinetic energy of the particles decreases and the compaction of the material on the substrate becomes less efficient (Elfordy et al. 2008). The authors attributed the improved mechanical properties to the higher compaction, and hence, higher density achieved with the projection casting method. In contrast, almost no compaction occurs with the conventional mixing and casting technique, resulting in highly porous materials with very low bulk density and poor mechanical strength after curing. 
Other studies have also confirmed that density, which is a function of compaction, as a crucial production factor affecting the performance of the lime-hemp concrete (BarnaHunek et al. 2015; Abdellatef et al. 2020).

Nonetheless, the higher compaction and density values achieved with the projection casting process (Elfordy et al. 2008) meant that its usefulness as a viable thermal insulator in temperate climates was compromised due to the increased thermal conductivity of Hempcrete. However, it opens up new possibilities for the elaboration of lime-based loadbearing composites with bio-aggregates in applications where a favorable compromise between thermal insulation and mechanical strength properties can be achieved.

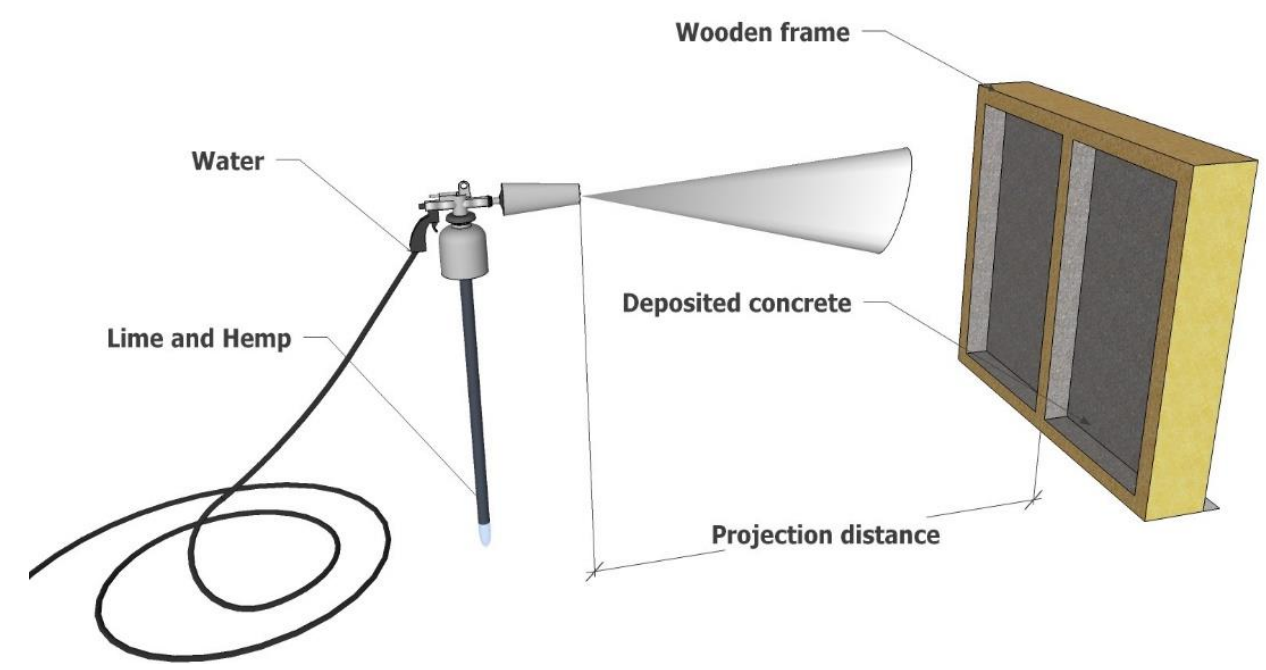

Fig. 2. Schematic diagram illustrating projection casting of lime-based composites

\section{LIGNOCELLULOSIC COMPOSITES FROM MAGNESIUM-BASED CEMENT}

The major motivation for the development of MgO-based cement has been driven by environmental aspects such as lower calcination temperatures compared to those of Portland cement. Equally, the ability of $\mathrm{MgO}$ to absorb $\mathrm{CO}_{2}$ from the atmosphere (as much $\mathrm{CO}_{2}$ as was emitted during manufacture) makes it a carbon-neutral cement (Walling and Provis 2016). The following presents recent research on various Mg-based composites containing a wide range of fibers and their properties (Fig. 3.).

\section{Magnesium Phosphate Cement (MPC)}

Magnesium phosphate cement (MPC) is a new type of fast-setting inorganic mineral binder. Curing is based on an acid-base neutralization reaction of metal cations from calcined magnesia $(\mathrm{MgO})$ with phosphate anions from ammonium dihydrogen phosphate $\left(\mathrm{NH}_{4} \mathrm{H}_{2} \mathrm{PO}_{4}\right)$ or potassium dihydrogen phosphate $\left(\mathrm{KH}_{2} \mathrm{PO}_{4}\right)$. This leads to the formation the hydration products struvite $\left(\mathrm{MgNH}_{4} \mathrm{PO}_{4} .6 \mathrm{H}_{2} \mathrm{O}\right)$ or K-struvite $\left(\mathrm{MgKPO}_{4} .6 \mathrm{H}_{2} \mathrm{O}\right.$ ), respectively (You et al. 2015; Wagh 2016; Qin et al. 2018a; Wang et al. 2018). The initial development of MPCs was motivated by the need for an entirely inorganic and nontoxic chemically-bonded ceramic (CBC) with fast-setting properties for dental application (Wagh 2016). Due to their favorable properties, they have now found a wide range of applications, including materials for nuclear shielding and immobilization/ 
encapsulation of highly hazardous industrial wastes (Wagh et al. 2001; Covill et al. 2011; Wagh 2016), coatings and adhesives (Laufenberg and Aro 2004; Ahmad et al. 2018; Qin et al. 2018a; Ahmad et al. 2020) as well as for rapid repair of concrete structures and highperformance civil engineering applications (Jeong and Wagh 2003; Laufenberg and Aro 2004; Amiandamhen et al. 2016; Wagh 2016; Walling and Provis 2016; Ahmad and Chen 2020).

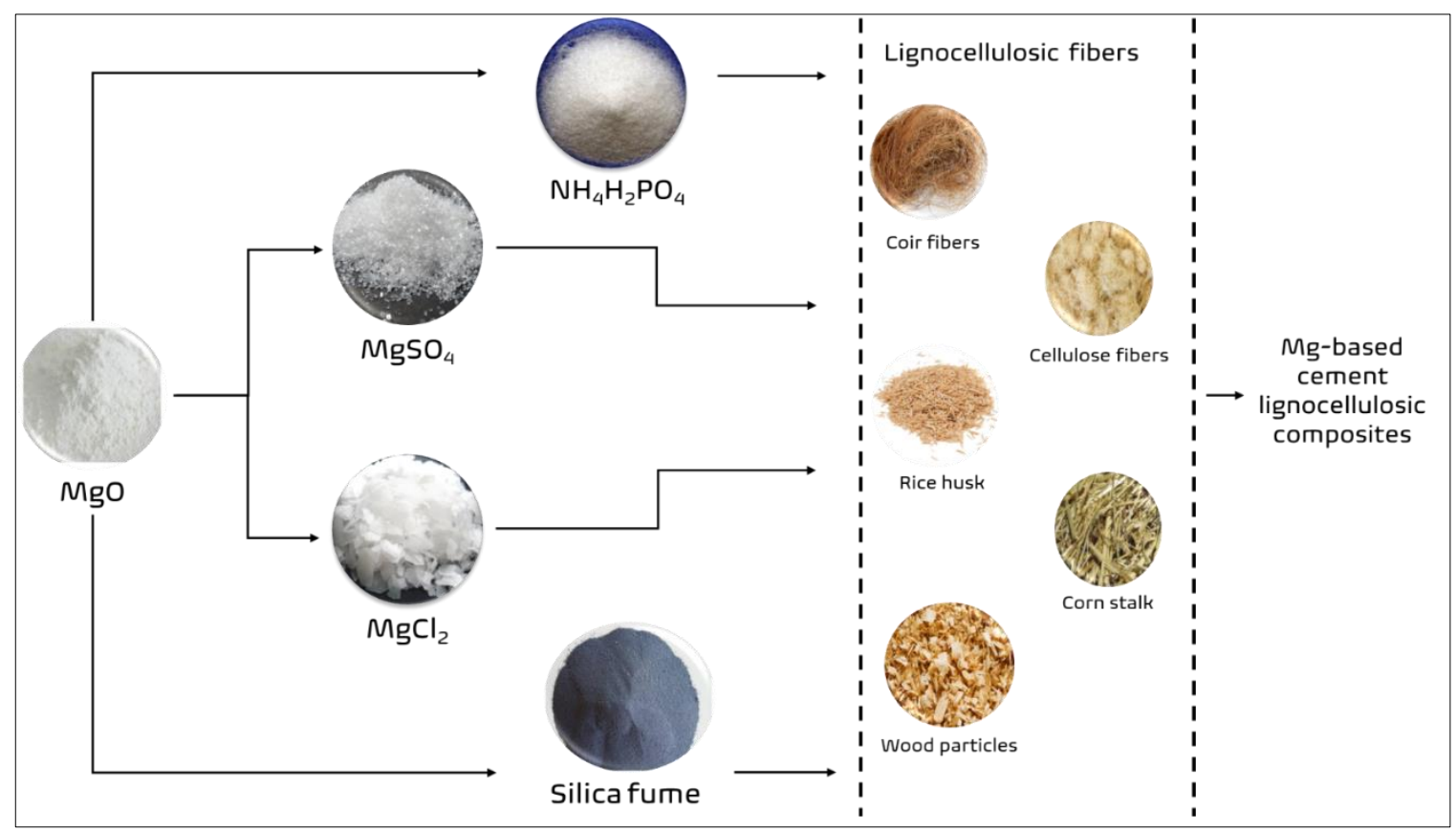

Fig. 3. Schematic diagram illustrating the production of Mg-based composites

\section{Magnesium phosphate cement (MPCs) - lignocellulosic composites}

Previous studies have confirmed the unique advantages of MPCs over other inorganic mineral binders, making them suitable and highly adaptable for versatile applications in the production of mineral binder-bonded composite. These include ready availability of the raw materials (natural minerals) and compatibility with existing equipment and processes for cementitious products (Jeong and Wagh 2003; Laufenberg and Aro 2004), low water requirements, low dry shrinkage (Li and Chen 2013; Wagh 2016; Ahmad et al. 2018), and fast setting at ambient temperature with high early and long-term strength (You et al. 2015; Lu and Chen 2016; Ahmad et al. 2018, 2019).

Similar to other rapid-curing cementitious materials, MPCs are also very brittle (low fracture toughness) with low strain capacity and crack resistance, limiting their utility in applications with high impact or flexural loads (Li et al. 2015; Qin et al. 2018a; Wang et al. 2018; Zhang et al. 2020). A wide range of natural and synthetic fibers, however, can be used with the MPC matrix to produce materials with interesting properties (Péra and Ambroise 1998; Amiandamhen et al. 2016; Qin et al. 2018a; Wei et al. 2019; Zhang et al. 2020). Natural plant fibers are more competitive in improving the poor fracture toughness and crack resistance of MPC than their synthetic counterparts as well as in terms of reducing the carbon footprint, embodied energy and costs while improving the overall ecological profile of the composite (Amiandamhen et al. 2016; Zhang et al. 2020). Moreover, curing of MPC is not affected by plant extractives, as fast hydration and setting behavior of the MPC take precedence over the interaction of binder cations with the soluble 
extractives such as simple sugars and hemicelluloses in natural fibers (Wang et al. 2017; Wang et al. 2018). This renders the MPCs suitable for the production of high value-added composites from a wide variety of lignocellulosic wastes/agricultural residues compared to other cementitious binders (Laufenberg and Aro 2004; Amiandamhen et al. 2019). Unlike OPC and lime-based binders, which form entirely alkaline hydrate products, the MPC slurry has a near-neutral $\mathrm{pH}$. This is due to the acid-base reaction, which makes it highly compatible with lignocellulosic materials without additional costs of energyintensive processes such as pre-treatment, drying, and precuring (Laufenberg and Aro 2004; Wagh 2016; Ahmad et al. 2018).

Most importantly, MPCs can incorporate a high proportion of lignocellulosic fibers and allow shorter curing time at near room temperatures to yield composites that are stable over a wider range of $\mathrm{pH}$. Still, they possess the superior technical properties of ceramics such as hardness, high compression, and resistance to chemical attack (Jeong and Wagh 2003; Laufenberg and Aro 2004; Wagh 2016; Qin et al. 2018a; Wang et al. 2018).

Despite the suitability of MPC for the development of plant-based composite products, there have been fewer studies on plant-based MPC concrete compared to OPC and lime-based concretes (Amiandamhen et al. 2019). Various studies report on concretes based on lignocellulosic wastes/agricultural residues and MPC binder formulations modified by various mineral admixtures (Table 2). Amiandamhen et al. (2019) recently reviewed these plants-based MPC materials.

\section{Magnesium Oxychloride Cement (MOC)}

Magnesium oxychloride cement (MOC), also known as sorel cement, is a nonhydraulic (air-hardening) cementitious material of low alkalinity, which is formed by mixing calcined magnesium oxide $(\mathrm{MgO})$ powder with aqueous magnesium chloride $\left(\mathrm{MgCl}_{2}\right)$ solution. MOCs, in general, exhibit several properties superior to OPC including higher setting speed, lower thermal conductivity and higher temperature resistance, better mechanical resilience (shock-resistance), and lower shrinkage and creep. In addition, they possess high resistance to chemicals and abrasion, high fire resistance, low carbon emission, less embodied energy, and high durability (Montle and Mayhan 1974; Zhou and Li 2012; Karthikeyan et al. 2014; Li et al. 2020). Its production process is relatively low cost (lower calcination temperatures) and makes use of a wide array of raw material sources, including industrial waste streams, further lowering the overall environmental profile of its products (Li et al. 2003; Walling and Provis 2016; Li et al. 2020). The primary application of MOC is as flooring material and concrete repair works, owing to its fast curing, resistance to accumulation of static charge, very hard, tough, and durable nature as well as its attractive, marble-like appearance (Sorell and Armstrong 1976; Walling and Provis 2016). Tables 2 and 3 present the production parameters and mechanical properties of lignocellulosic composites based on magnesium cement.

\section{Magnesium oxychloride cement (MOC) lignocellulosic composites}

In addition to its traditional use in flooring applications, certain unique properties of MOC cement have promoted its adoption in the manufacture of composites with functional properties. These include its capacity to bond with large quantities and a wide variety of inert fillers ranging from mineral to lignocellulosic materials with high strength properties at the same time (Karthikeyan et al. 2014; Walling and Provis 2016). MOC cement, just like the OPC and MPC, is a typical brittle material (Chen et al. 2019a). The incorporation of fibers is an effective approach to increase its toughness. 
Table 2. Overview of Mg-based Lignocellulosic Composites

\begin{tabular}{|c|c|c|c|c|c|c|c|c|}
\hline Type & $\begin{array}{l}\text { Type of } \\
\text { Fiber }\end{array}$ & $\begin{array}{c}\text { Amount } \\
\text { of Fibers } \\
(\%)\end{array}$ & $\begin{array}{l}\text { Length } \\
\text { of } \\
\text { Fibers } \\
\text { (mm) }\end{array}$ & $\begin{array}{l}\text { Formation } \\
\text { Technique }\end{array}$ & $\begin{array}{l}\text { Density } \\
\left(\mathrm{kg} / \mathrm{m}^{3}\right)\end{array}$ & Fillers & $\begin{array}{c}\text { Strength } \\
\text { (MPa) }^{\star}\end{array}$ & Ref. \\
\hline \multirow{10}{*}{ MPC } & $\begin{array}{l}\text { Wood } \\
\text { waste }\end{array}$ & $20 \mathrm{wt} \%$ & $\mathrm{n} / \mathrm{a}$ & $\begin{array}{c}\text { Casting, } \\
160 \times 160 \times \\
15 \mathrm{~mm}\end{array}$ & 1650 & $\begin{array}{l}\text { Alumina, } \\
\text { Red mud }\end{array}$ & $\begin{array}{l}\text { CM: 56 } \\
\text { MPa for } \\
20 \% \text { fiber }\end{array}$ & $\begin{array}{c}\text { Wang et } \\
\text { al. } \\
(2017)\end{array}$ \\
\hline & $\begin{array}{l}\text { Waste- } \\
\text { paper }\end{array}$ & $\mathrm{n} / \mathrm{a}$ & $\mathrm{n} / \mathrm{a}$ & $\begin{array}{c}\text { Casting, } \\
165 \times 165 \\
\mathrm{~mm}\end{array}$ & $\begin{array}{c}1112 \text { to } \\
1177\end{array}$ & FA & $\begin{array}{c}\text { CM: } 3.36 \\
\mathrm{MPa}\end{array}$ & $\begin{array}{c}\text { Donahue } \\
\text { and Aro } \\
\text { (2010) }\end{array}$ \\
\hline & $\begin{array}{l}\text { Sugar } \\
\text { maple }\end{array}$ & $\mathrm{n} / \mathrm{a}$ & $\mathrm{n} / \mathrm{a}$ & $\begin{array}{c}\text { Casting, } \\
\text { d- } 6.35 \mathrm{~mm} \\
\text { L- } 25.4 \mathrm{~mm}\end{array}$ & $\mathrm{n} / \mathrm{a}$ & $\begin{array}{c}\text { PC, } \\
\text { VCAS, } \\
\text { WO }\end{array}$ & $\mathrm{n} / \mathrm{a}$ & $\begin{array}{c}\text { Chi and } \\
\text { Englund } \\
(2014)\end{array}$ \\
\hline & $\begin{array}{l}\text { Acacia } \\
\text { species }\end{array}$ & $\mathrm{n} / \mathrm{a}$ & $1 \mathrm{~mm}$ & $\begin{array}{c}\text { Casting, } \\
218 \times 77 \times 40 \\
\mathrm{~mm}^{3}\end{array}$ & $\begin{array}{l}630 \text { to } \\
950\end{array}$ & FA & $\begin{array}{c}\mathrm{CM}: 4.51 \\
\mathrm{MPa}\end{array}$ & $\begin{array}{c}\text { Amianda } \\
\text { mhen et } \\
\text { al. } \\
(2017)\end{array}$ \\
\hline & $\begin{array}{l}\text { Rape } \\
\text { stalk } \\
\text { (RS) }\end{array}$ & $\begin{array}{c}5 \text { to } 30 \\
\text { wt } \%\end{array}$ & $\begin{array}{c}3 \text { to } 15 \\
\mathrm{~mm}\end{array}$ & Casting & $\begin{array}{c}575 \text { to } \\
1650\end{array}$ & FA & $\begin{array}{l}\text { CM: } 25 \\
\text { MPa for } \\
5 \% \text { fiber }\end{array}$ & $\begin{array}{l}\text { Liu and } \\
\text { Chen } \\
(2015)\end{array}$ \\
\hline & $\begin{array}{l}\text { Corn- } \\
\text { stalk } \\
\text { (CS) } \\
\end{array}$ & $\begin{array}{l}5 \text { to } 30 \\
\text { (Vol. \%) }\end{array}$ & $\begin{array}{c}9 \text { and } 14 \\
\mathrm{~mm}\end{array}$ & casting & $\begin{array}{l}557- \\
2253\end{array}$ & FA & $\begin{array}{c}\text { CM: } 9.44 \\
\text { MPa for } \\
30 \% \text { fiber }\end{array}$ & $\begin{array}{c}\text { Ahmad } \\
\text { et al. } \\
\text { (2018) } \\
\end{array}$ \\
\hline & $\begin{array}{l}\text { Corn- } \\
\text { stalk } \\
\text { (CS) }\end{array}$ & $\mathrm{n} / \mathrm{a}$ & $\mathrm{n} / \mathrm{a}$ & $\begin{array}{c}\text { Casting } \\
70 \times 70 \times 70 \\
\mathrm{~mm}^{3}\end{array}$ & $\mathrm{n} / \mathrm{a}$ & $\mathrm{n} / \mathrm{a}$ & $\begin{array}{c}\text { CM: } 3.83 \\
\mathrm{MPa}\end{array}$ & $\begin{array}{l}\text { Wei et } \\
\text { al. } \\
(2019)\end{array}$ \\
\hline & $\begin{array}{c}\text { Coir fiber } \\
\text { (CF) }\end{array}$ & $\begin{array}{c}3 \\
\text { (Vol. \%) }\end{array}$ & $\begin{array}{c}5 \text { to } 30 \\
\mathrm{~mm}\end{array}$ & $\begin{array}{l}\text { Casting } \\
40 \times 40 \times 40 \\
\mathrm{~mm}^{3}\end{array}$ & $\mathrm{n} / \mathrm{a}$ & FA & $\begin{array}{l}\text { FI: } 13.48 \\
\text { MPa for } \\
3 \% \text { fiber }\end{array}$ & $\begin{array}{c}\text { Zhang et } \\
\text { al. } \\
\text { (2020a) }\end{array}$ \\
\hline & $\begin{array}{c}\text { Coir fiber } \\
\text { (CF) }\end{array}$ & $\begin{array}{c}1 \text { to } 4 \\
\text { (Vol. \%) }\end{array}$ & $20 \mathrm{~mm}$ & $\begin{array}{l}\text { Casting } \\
40 \times 40 \times 40 \\
\mathrm{~mm}^{3}\end{array}$ & $\mathrm{n} / \mathrm{a}$ & FA & $\begin{array}{l}\text { FI: } 7.31 \\
\text { MPa for } \\
3 \% \text { fiber }\end{array}$ & $\begin{array}{c}\text { Zhang et } \\
\text { al. } \\
\text { (2020b) }\end{array}$ \\
\hline & $\begin{array}{c}\text { Coir fiber } \\
\text { (CF) }\end{array}$ & 3 wt $\%$ & $\begin{array}{c}5 \text { to } 30 \\
\mathrm{~mm}\end{array}$ & $\begin{array}{c}\text { Casting } \\
40 \times 70 \times 40 \\
\mathrm{~mm}^{3}\end{array}$ & $\mathrm{n} / \mathrm{a}$ & FA & $\begin{array}{l}\text { CM: } 56.5 \\
\text { MPa for } \\
3 \% \text { fiber }\end{array}$ & $\begin{array}{c}\text { Jiang et } \\
\text { al. } \\
\text { (2020a) }\end{array}$ \\
\hline \multirow{3}{*}{ MOC } & Sawdust & $\mathrm{n} / \mathrm{a}$ & $\mathrm{n} / \mathrm{a}$ & extrusion & $\begin{array}{l}996- \\
1210\end{array}$ & $\begin{array}{l}\text { PAM, } \\
\text { CMC, and } \\
\text { Perlite }\end{array}$ & $\begin{array}{c}\text { FI: } 3.7 \\
\mathrm{MPa}\end{array}$ & $\begin{array}{l}\text { Zhou } \\
\text { and Li } \\
(2012)\end{array}$ \\
\hline & $\begin{array}{l}\text { Corn- } \\
\text { stalk } \\
\text { (CS) }\end{array}$ & $\begin{array}{c}* * 20 \text { to } \\
120 \\
w t \%\end{array}$ & $\begin{array}{c}1.25 \text { to } \\
4.75 \mathrm{~mm}\end{array}$ & $\begin{array}{l}\text { Casting } \\
40 \times 40 \times \\
160 \mathrm{~mm}^{3}\end{array}$ & 816 & $\begin{array}{c}\text { EVA } \\
\text { Emulsion }\end{array}$ & $\begin{array}{c}\text { FI: } 3.65 \\
\text { MPa } \\
\text { CM: } 4.69 \\
\text { MPa }\end{array}$ & $\begin{array}{l}\text { Li et al. } \\
\text { (2017) }\end{array}$ \\
\hline & $\begin{array}{c}\text { Corn- } \\
\text { stalk } \\
\text { (CS) and } \\
\text { sawdust }\end{array}$ & $\begin{array}{c}5,10 \text {, and } \\
15 \\
\text { wt } \%\end{array}$ & $\mathrm{n} / \mathrm{a}$ & $\begin{array}{l}\text { Casting } \\
40 \times 40 \times \\
160 \mathrm{~mm}^{3}\end{array}$ & $\mathrm{n} / \mathrm{a}$ & $\begin{array}{l}\text { CBP and } \\
\text { TP }\end{array}$ & $\begin{array}{c}\text { CM: } 73 \\
\mathrm{MPa}\end{array}$ & $\begin{array}{c}\text { Chen et } \\
\text { al. } \\
(2019)\end{array}$ \\
\hline
\end{tabular}


Table 3. Overview of Mg-based Lignocellulosic Composites (Contd.)

\begin{tabular}{|c|c|c|c|c|c|c|c|c|}
\hline Type & $\begin{array}{c}\text { Type of } \\
\text { Fiber }\end{array}$ & $\begin{array}{c}\text { Amount } \\
\text { of } \\
\text { Fibers } \\
(\%)\end{array}$ & $\begin{array}{l}\text { Length } \\
\text { of } \\
\text { Fibers } \\
\text { (mm) }\end{array}$ & $\begin{array}{l}\text { Formation } \\
\text { Technique }\end{array}$ & $\begin{array}{l}\text { Density } \\
\left(\mathrm{kg} / \mathrm{m}^{3}\right)\end{array}$ & Fillers & $\begin{array}{c}\text { Strength } \\
(\mathrm{MPa})^{\star}\end{array}$ & Ref. \\
\hline \multirow{3}{*}{ MOSC } & $\begin{array}{l}\text { Cellulose } \\
\text { fibers }\end{array}$ & $3 w t \%$ & 1.15 & $\begin{array}{c}\text { Vacuum } \\
\text { and } \\
\text { compressio } \\
n \\
30 \times 100 \times \\
5 \mathrm{~mm}^{3}\end{array}$ & $\mathrm{n} / \mathrm{a}$ & $\begin{array}{c}\mathrm{CaCO}_{3} 85 \\
\text { wt\%, } \\
\text { glass } \\
\text { fiber } 1.8 \\
\text { wt } \%\end{array}$ & $\begin{array}{l}\text { FI: } 9.65 \\
\text { MPa for } \\
3 \% \text { fiber }\end{array}$ & $\begin{array}{c}\text { Gomes \& } \\
\text { Camarini } \\
2014\end{array}$ \\
\hline & Rice husk & $\begin{array}{l}10 \text { to } 30 \\
\text { (vol. \%) }\end{array}$ & $n / a$ & $\begin{array}{c}\text { Casting } \\
70.7 \times 70.7 \times \\
70.7 \mathrm{~mm}^{3}\end{array}$ & $\begin{array}{l}800 \text { to } \\
2000\end{array}$ & $\begin{array}{c}\text { Citric acid } \\
\text { (wt 5\%), } \\
\text { boric acid } \\
\text { (wt 5\%) }\end{array}$ & $\begin{array}{c}\text { CM: } \\
124.8 \\
\text { MPa for } \\
10 \% \text { fiber }\end{array}$ & $\begin{array}{l}\text { Wang et } \\
\text { al. } 2020\end{array}$ \\
\hline & Rise husk & $\begin{array}{l}10 \text { to } 32 \\
\text { (vol. \%) }\end{array}$ & $\mathrm{n} / \mathrm{a}$ & $\begin{array}{c}\text { Casting } \\
70.7 \times 70.7 \times \\
70.7 \mathrm{~mm}^{3}\end{array}$ & $\begin{array}{c}451 \text { to } \\
1722\end{array}$ & $\begin{array}{c}\text { Citric acid } \\
\text { (wt 5\%) }\end{array}$ & $\begin{array}{c}\text { CM: } 70.4 \\
\text { MPa for } \\
10 \% \text { fiber }\end{array}$ & $\begin{array}{l}\text { Qin et al. } \\
2018 b\end{array}$ \\
\hline MS & $\begin{array}{l}\text { Pine and } \\
\text { eucalyptus } \\
\text { cellulosic } \\
\text { fibers }\end{array}$ & $8 w t \%$ & $\begin{array}{c}0.2 \text { to } \\
2.2\end{array}$ & $\begin{array}{c}\text { Vacuum } \\
\text { and } \\
\text { compressio } \\
\mathrm{n} 200 \times 200 \\
\times 6 \mathrm{~mm}^{3}\end{array}$ & $\begin{array}{c}1390 \text { to } \\
1520\end{array}$ & $\begin{array}{c}\text { limestone } \\
23 \text { wt\% }\end{array}$ & $\begin{array}{l}\text { FI: } 9.23 \\
\text { MPa for } \\
8 \% \text { fiber }\end{array}$ & $\begin{array}{c}\text { Marmol \& } \\
\text { Savastano } \\
2015\end{array}$ \\
\hline
\end{tabular}

Adding lignocellulosic waste materials/agricultural residues has been considered as an economic and environmentally friendly method that enhances the technical properties of MOC concrete (Zhou and Li 2012; Li et al. 2017; Chen et al. 2019a). Additionally, MOC cement exhibits a characteristic yellowish color, which is close to the color of natural wood, as well as low alkalinity, and resistance to the inhibitory effect of extractives. These properties have made it desirable for the production of mineral binder-bonded composites from wood particles as well as a wide range of biomass wastes/agricultural residues, without the aging and setting problems commonly experienced with (highly alkaline) OPC binder (Zhou and Li 2012). Nevertheless, MOC's poor moisture resistance in exterior applications has slowed down its wide application as composites for construction engineering using hydrophilic lignocellulosic fibers.

Hence, the improvement of the poor water resistance and other technical properties of MOC has attracted much attention from researchers, because it has a crucial influence on the use of MOC-based materials under exterior conditions (Guo et al. 2018).

\section{Magnesium Oxysulfate Cement (MOSC)}

Magnesium Oxysulfate Cement (MOSC), a non-conventional material belongs to the class of Mg-based cement. Compared to OPC, MOSC features various advantages such as fire resistance, low thermal conductivity, low density, and especially adequate compatibility with lignocellulosic materials (Gomes and Camarini 2014). Along with other Mg-based cements, MOSC cements are considered environmentally friendly due to their lower carbon emissions released predominantly in the calcination process of the raw material (Mo et al. 2016). MOSC is formed by the reaction of hydrated magnesium oxide and magnesium sulfate at ambient temperature:

$$
\mathrm{MgO}+\mathrm{H}_{2} \mathrm{O} \rightarrow \mathrm{Mg}(\mathrm{OH})_{2}
$$




$$
5 \mathrm{Mg}(\mathrm{OH})_{2}+\mathrm{MgSO}_{4} \cdot 7 \mathrm{H}_{2} \mathrm{O}+\mathrm{H}_{2} \mathrm{O} \rightarrow 5 \mathrm{Mg}(\mathrm{OH})_{2} \cdot \mathrm{MgSO}_{4} \cdot 8 \mathrm{H}_{2} \mathrm{O}
$$

\section{Magnesium oxysulfate (MOSC) cement- lignocellulosic composites}

A limited number of studies have been conducted in the field of MOSC cementbonded lignocellulosic boards. Cellulosic fibers-MOSC composites were prepared using calcium carbonate as an inert filler (Gomes and Camarini 2014). Flexural strength displayed a marginal decrease with the increase of aging cycles; however, the durability of the fiberboards after aging was still very promising. Recently, Wang et al. (2020) prepared lightweight building materials from rice husk bonded with MOSC and a foaming agent. For the preparation process, a small fraction of citric acid was added to the reagent mixture. The weak citric acid enhanced the compressive strength, as it catalyzed the formation of finer crystals. Rice husk-MOSC composites, however, were quite sensitive to various wetting-drying cycles. After numerous aging cycles, the compression strength decreased considerably, particularly when the porosity of the sample was high. When the rice husk content was $10 \mathrm{wt} \%$, compression strength was not affected, but, when the rice husk content was increased to $70 \mathrm{wt} \%$, it declined significantly. In an analogous study (Qin et al. 2018b), the compression strength of rice husk-MOSC composites increased with increasing density while insulation properties worsened. A higher amount of rice husks in the composite eventually leads to higher drying shrinkage. A direct comparison with other studies is presented in Tables 2 and 3.

The application of MOSC cement is often limited due to the lack of mechanical strength compared to OPC. Lightweight MOS cement-lignocellulosic composites could be used for interior non-structural applications as they have exceptional sound-, fire-, and water-resistance as well as thermal insulation properties (Gomes and Camarini 2014). The less alkaline environment arising from the hydration process has a positive effect on the curing behavior compared to OPC, as lower amounts of alkaline soluble polysaccharides are dissolved in the cement paste, which affects crystallization.

\section{Magnesium Silica Cement (MSC)}

Magnesium silicate hydrate (MSH) is a matrix formed from the reaction of $\mathrm{MgO}$ and silica (silicon dioxide). The factors controlling the formation of MSH include the ratio and characteristics of the reagents, alkalinity of the mixture, and temperature (Jin and AlTabbaa 2014). Comparing OPC and Magnesium Silica Cement (MSC), the two main hydrated compounds from the former one are calcium silicate hydrate and portlandite $\left(\mathrm{Ca}(\mathrm{OH})_{2}\right)$, whereas, in the case of the latter one, MSH and brucite $\left(\mathrm{Mg}(\mathrm{OH})_{2}\right)$ are formed (Jin and Al-Tabbaa 2014; Zhang et al. 2014; Lothenbach et al. 2015). Even though there are many similarities in the crystal structure, it is assumed that MSC required more water than OPC to form completely hydrated gels (Chen et al. 2013). An excess of water at the initial stages can be problematic because it can increase the number of capillary pores and, as a result, decrease the mechanical performance (Marmol and Savastano 2015).

\section{Magnesium silica (MS) cement - lignocellulosic composites}

Few studies have reported on magnesium silica (MS) cement-lignocellulosic fiber composites. Marmol and Savastano (2015) investigated the degradation of MSC reinforced with pine and eucalyptus wood fibers. In order to cast the slurry, a dewatering process using a vacuum pump connected with the drilled mold was utilized, followed by a pressing step (Fig. 4.). This technique, analogously with other casting methods, has been widely 
used to produce OPC-fiber composites and corresponds to the Hatschek process (Ardanuy et al. 2015). The MS cement binder was able to maintain the strength properties of the composite and to preserve the wood fibers' integrity after several aging cycles, while OPC suffered from strength losses. After 28 days of curing, OPC-wood fiber composites exhibited higher flexural strength than MS cement composites. The authors attributed the lower strength to the higher water-cement ratio required for the hydration of $\mathrm{MgO}-\mathrm{SiO}_{2}$. Aging over 200 cycles had no negative effect on flexural strength of MSC composites. In contrast, OPC composites suffered a significant loss of Modulus of Rupture after ageing. Also, in the case of MSC composites, the interfacial transition zone (ITZ) was densified, thus improving the adherence between the fiber and the matrix. In OPC composites, however, the presence of portlandite on the fiber surface can degrade the fiber and reduce the mechanical properties, while in MSC, such mineralization did not occur.

The authors suggested that during aging, unreacted magnesium hydroxide reacts with $\mathrm{SiO}_{2}$, forming a resistant $\mathrm{M}-\mathrm{H}-\mathrm{S}$ matrix that protects the fibers (Marmol and Savastano 2015). Durability (maintaining strength) during aging and resistance to weathering appear to be the distinctive property of MSC - lignocellulosic composites.

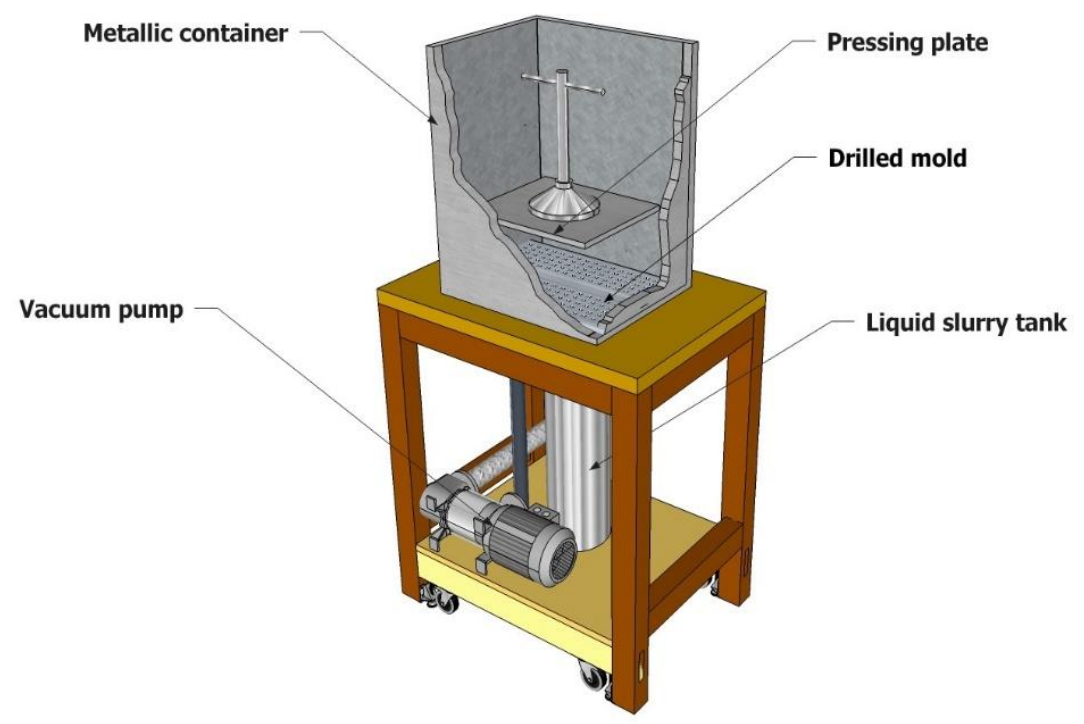

Fig. 4. Schematic diagram illustrating the vacuum dewatering process followed by pressing. A laboratory-scale Hatschek process

\section{Factors Affecting the Performance of Mg-based Cement}

Similar to other inorganic mineral binder-bonded composites, the performance of $\mathrm{Mg}$-cement-bonded composites as green building materials is critically dependent on the production parameters.

\section{Effect of modifiers/fillers, MPC}

The hydration reaction of MPC binder in the presence of water proceeds very rapidly, accompanied by an increase in hydration temperature, owing to the exothermic setting (curing) reactions. This results in difficulties with mixing and casting, with attendant effects on the mechanical properties of the resulting material (Yang et al. 2014). In addition, due to the instability of MPC hydration products to water, MPC materials may exhibit compromised performance when exposed to long-term outdoor conditions or humid 
environments, further reducing the strength properties of the material ( $\mathrm{Lu}$ and Chen 2016; Wang et al. 2017). Thus, modifiers are needed to control the reactions and setting rate as well as to improve the resistance of MPC products to water. Borax and boric acid are the most common effective additives for reducing the hydration rate and curing temperature of MPC, to allow enough working time (Hall et al. 2001; Yang et al. 2014; You et al. 2015; Wang et al. 2017). However, issues persist in terms of stability and mechanical performance in a highly humid environment. To circumvent this, incorporation of mineral admixtures or industrial by-products as modifiers into MPC imparted significant improvements in moisture resistance, mechanical and functional properties of the resulting MPC concrete while lowering the overall product costs (Chi and Englund 2014; Liang et al. 2019a). These modifiers include fly ash and silica fume from utility plants (Wagh et al. 1997; Li and Chen 2013; Liu and Chen 2015; Li et al. 2016; Zheng et al. 2016; Liao et al. 2017; Ahmad et al. 2018), mineral wastes (Fan and Chen 2015; Wang et al. 2017), metallic slag (Tan et al. 2016; Chen et al. 2017) as well as natural (mineral) pozzolanic materials such as metakaolin (Lu and Chen 2016; Li et al. 2016; Liu and Chen 2016; Shi et al. 2019).

The principal mineral modifier used for lignocellulosic-MPC composites is fly ash (FA), an industrial by-product (Table 2). FA can significantly improve the technical properties of the MPC system, even at higher mass contents (up to $40 \mathrm{wt} \%$ ) (Ding and $\mathrm{Li}$ 2005a). Additionally, FA inclusion at certain mass content can reduce the total heat evolution during hydration, increase setting time and flowability of fresh MPC paste as well as improve the mechanical strength and moisture-related properties of MPC mortar (Donahue and Aro 2010; Li and Feng 2010; Li and Chen 2013). The addition of FA improves the microstructural compactness of MPC paste, and thus its mechanical performance, through the dual mechanisms of physically filling the pores of MPC paste and the participation of its alumina $\left(\mathrm{Al}_{2} \mathrm{O}_{3}\right)$ and amorphous silica $\left(\mathrm{SiO}_{2}\right)$ components in the hydration reaction to form a new cementitious gel. This new product (gel) makes the MPC structure denser while generating more binder in the mixture (Laufenberg and Aro 2004; Ding and Li 2005a,b; Donahue and Aro 2010; Li and Feng 2010).

The effect of admixing OPC, wollastonite (WO), and vitrified calcium aluminosilicates (VCAS) on the bonding interface of sugar maple (Acer saccharum) wood/MPC composites was evaluated using a mixture design (Chi and Englund 2014). A combination of WO and VCAS in an MPC mix mutually promoted the interfacial shear strength $\left(\tau_{\mathrm{i}}\right)$ of the composites. The materials modified with VCAS exhibited higher water sorption than those modified with WO and OPC with a corresponding rapid loss of bond integrity after one day of immersion in water. The MPC binder content (level), however, is the primary factor affecting the interfacial bond properties of the wood/MPC materials, irrespective of the type of modifier used (Chi and Englund 2014).

Alumina $\left(\mathrm{Al}_{2} \mathrm{O}_{3}\right)$ and red mud $\left(\mathrm{Fe}_{2} \mathrm{O}_{3}\right)$ were used as sustainable additives to improve the water-resistance and strength properties of MPC particleboards made from wood waste (Wang et al. 2017). The partial replacement of $\mathrm{MgO}$ with alumina or red mud at an $\mathrm{Mg} / \mathrm{Al}$ or $\mathrm{Mg} / \mathrm{Fe}$ optimal molar ratio of 10:1 facilitated the formation of amorphous $\mathrm{Mg}-\mathrm{Al}$ or Mg-Al-Fe phosphate gel, respectively, which enhanced compressive strength. While alumina-MPC particleboards exhibited improved short-term (24-h) water resistance and strength retention, red-mud-modified boards exhibited higher long-term water resistance and enhanced strength retention with reduced water absorption after 72-h water immersion. This is attributed to the stable scaly-like $\mathrm{Mg}$-Al-Fe phosphate gel. Additionally, red mud imparted excellent compatibility of MPC binder with wood waste and facilitated the extension of both the initial and final setting time of the MPC mix. 


\section{Effect of modifiers/fillers, MOC}

Various fillers/modifiers have been utilized to improve MOC composites. In a recent study, recycled clay brick powder (CBP) was investigated as an alternative low-cost waste pozzolanic material for MOC mortar reinforced with agricultural residues, namely corn stalk and wood sawdust (Chen et al. 2019). Due to the higher water absorption capacity of the CBP, the fluidity and workability of freshly blended agro-waste MOC mortars consistently decreased with increasing CBP content up to a maximum CBP content of $15 \%$. Other properties such as specific gravity increased, while the flexural strength (more than $25 \%$ decline) and water absorption capacity of the MOC mortars significantly decreased with increasing CBP content up to $35 \%$. Due to the pore filling and pozzolanic potential of the CBP, the MOC composites became denser and more brittle with increasing $\mathrm{CBP}$ content, thereby limiting the ingress of moisture into the structure, while adversely impacting the flexural strength.

Another study assessed the effects of adding ethylene-vinyl acetate (EVA) emulsion as a modifier on the water resistance, density, thermal conductivity, and mechanical properties of corn-stalk-MOC (C-MOC) composites ( $\mathrm{Li}$ et al. 2017). Microscopic analysis revealed that EVA emulsion exhibited good compatibility with the magnesium oxychloride cement by interacting synergistically with the fiber and matrix components. It thus enhances their interfacial bonding performance by forming a thin film on the outer surface of the corn stalk, increases the roughness of the straw surface, and reduces the gap between the stalk. Increasing EVA emulsion content resulted in a corresponding reduction of the water absorption capacity of C-MOC composites, while it increased the density and coefficient of thermal conductivity, respectively (Li et al. 2017).

\section{Effect of modifiers/fillers, MOSC}

Wang et al. (2020) showed that the addition of the weak acids citric acid and boric acid can significantly increase the compressive strength of MOSC composites at different curing ages. Citric acid was more effective and greatly enhanced the compressive strength after 28 days of curing. This can be attributed to citric acid's ability to catalyze the production of a greater number of fine needle-like crystals. Adding tartaric acid gave analogous results regarding the enhancement of flexural and compression strength (Wu et al. 2017). Microscopic observations indicated that tartaric acid promotes the formation of the needle-like high-strength phase of $5 \mathrm{Mg}(\mathrm{OH})_{2} \cdot \mathrm{MgSO}_{4} \cdot 7 \mathrm{H}_{2} \mathrm{O}$ and inhibits the formation and growth of the $\mathrm{Mg}(\mathrm{OH})_{2}$ crystal phase.

\section{Effect of plant aggregate type, size, and volume content}

The type and volume content of plant-derived aggregates are important parameters with critical influence on the density and performance of mineral binder-bonded wood and plant fiber-based composites. Liu and Chen (2015) investigated rape stalk-MPC materials obtained by incorporating different sizes and volume contents of rape stalk (RS) in an MPC binder formulation containing $20 \%$ fly ash. RS-MPC concretes were realized, which satisfied the requirements for structural and insulating purposes. At RS contents $<20 \%$, the thermal conductivity decreased linearly with increasing RS size, owing to the morphological (honeycomb) structure and lower thermal conductivity of the rape stalk compared to the MPC matrix. However, improved early strength gain values of the concrete were observed with increasing RS content, while the concrete mixtures with the smallest RS size exhibited the highest early strength gain in the first hour. The compression strength of RS-MPC concrete decreased with increasing rape stalk content and size, due to 
the difficulty in packing large-sized RS aggregates at higher contents, thereby resulting in the development of voids in the concrete. This indicates that, aside from the poor RS/matrix interfacial adhesion and low mechanical strength of the rape stalk, increasing porosity of the composite material as a function of rape stalk size and content is a major factor contributing to the reduction of compressive strength of RS-MPC concrete (Liu and Chen 2015).

MPC composites containing large corn stalk (LCS) and small corn stalk (SCS) were investigated in terms of mechanical and physical properties. Increasing corn stalk content resulted in a corresponding decrease in the compressive strength and rate of strength gain during curing for CS-MPC concrete and increased the thermal conductivity and water absorption coefficient of the concrete accordingly. Corn stalk size significantly influenced the compressive strength of CS-MPC concretes. The SCS-MPC concrete exhibited higher thermal conductivity and lower water absorption coefficient compared to the LCS-MPC concrete (Ahmad et al. 2018).

The effects of coconut coir fibers $(\mathrm{CF})$ with different lengths and curing times were studied in terms of flexural strength, load-displacement behavior, and flexural toughness of MPC with CF lengths varying from 0 to $30 \mathrm{~mm}$ at various curing ages (Zhang et al. 2020). At both curing times, flexural strength and toughness of MPC initially increased with increasing CF length, but then they decreased when CF length exceeded $20 \mathrm{~mm}$. Ductility and elastic modulus displayed continuous increasing and decreasing trends, respectively with increasing $\mathrm{CF}$ length. After a curing period of 28 days, compressive strength, elastic modulus, and secant modulus decreased with increasing CF length. The $\mathrm{CF}$ length of $20 \mathrm{~mm}$ was the threshold for the maximum energy absorption, beyond which the value declined following a convex curve (Zhang et al. 2020b).

Jiang et al. (2020a) studied the effects of CF volume concentrations ( $0 \%$ to $4 \%)$ at two curing ages ( 7 and 28 days) on MPC flexural properties. CF showed similar effects on the flexural performances for MPC at both curing times, with specimens at 28 days exhibiting greater flexural strength, higher stiffness, and flexural toughness than those at 7 days. In addition, increasing $\mathrm{CF}$ volume concentration up to $3 \%$, sequentially enhanced the flexural toughness and compression strength (Jiang et al. 2020).

\section{Hybridization}

A hybrid usage of polyacrylamide (PAM) and carboxymethyl cellulose (CMC) was adopted as a cost-effective and efficient rheology-enhancing additive for wood-MOC cement composites (Zhuo and Li 2012). The authors were able to produce extruded lightweight wood-MOC cement composites to be used as full-scale door frame and door panels, with specific dry densities close to 1.0 , and nailability similar to natural hardwood. Incorporation of perlite, by replacing $50 \mathrm{wt} \%$ sawdust in the composite, resulted in materials with less die swell and better performance in resisting high temperatures. Aside from factors influencing the MOC binder properties and fiber-matrix interfacial interaction, the fiber content and distribution is a critical factor that greatly affects the performance properties of plant fiber-MOC composites (Li et al. 2017). The flexural strength of agro-waste MOC composites was enhanced by the addition of corn stalk (CS) and sawdust (SD), while the water sorption of mortars increased with increasing fiber content (Chen et al. 2019a). The induced increase in the flexural strength with the incorporation of agro-waste aggregates (i.e., CS and SD) was mainly attributed to the arbitrary distribution of the fibers in the mixture, thereby improving the continuity of the composite material and reducing internal defects when loaded. Contrarily, the 
incorporation of CS and SD fibers in the MOC reduced the compressive strength. This can be explained based on two factors: First, the incorporation of the inert fibers results in less compact materials, due to the poor fiber-matrix interfacial bonding in the MOC structure. In addition, it decreases the proportion of cementitious materials and thereby further reduces the hydration products responsible for bonding.

\section{LIGNOCELLULOSIC COMPOSITES FROM GEOPOLYMERS AND ALKALI ACTIVATED CEMENT}

\section{Geopolymers: Properties and Applications}

Geopolymers (mineral polymers resulting from geochemistry or geosynthesis) are inorganic polymer materials formed by polycondensation of mineral substances rich in silicon ( $\mathrm{Si}$ ) and aluminum ( $\mathrm{Al})$ in a strongly alkaline or acidic environment. When such (geopolymer) materials harden at ambient/room temperature like regular cement, they are referred to as "geopolymer cement". If they only harden under the influence of heat treatment, they are called "geopolymer binders" (Davidovits 2013). Geopolymer materials have emerged as a low embodied energy and eco-responsible alternative to conventional construction materials. They can be produced from a wide range of natural minerals or industrial waste streams such as metakaolin, fly ash, slag, silica fume, natural pozzolanic (ashes) materials as well as calcium or magnesium-containing minerals (Shalbafan et al. 2016; Bazan et al. 2020; Korniejenko et al. 2020a; Lemougna et al. 2020).

There is disagreement in the scientific community as to whether geopolymers should be classified as a subset of alkali-activated materials (AAM). According to a stateof-the-art report by RILEM (RILEM TC 224-AAM 2014), Alkali-Activated Materials (AAM) are defined as "the broadest classification, encompassing essentially any binder system derived by the reaction of an alkali metal source (solid or dissolved) with a solid silicate powder". These can be derived from a myriad of natural and industrial waste materials as precursors and regard geopolymers as a subset of this classification. However, for this study, geopolymers are treated as a separate group.

Detailed information on the various industrial by-products and waste materials used for geopolymer production including the reported compositions, mixtures, compressive strengths, and curing conditions for their pastes and mortars can be found in the review of Silva et al. (2019). The major oxide concentrations of various precursors used for the production of geopolymers and alkali-activated cements are depicted in a ternary phase diagram (Fig. 5.).

Owing to their high compressive strength, low shrinkage, resistance to corrosive environments, and high thermal stability as well as a high capacity to encapsulate foreign materials within their structure (Silva et al. 2019; Liang et al. 2019b; Korniejenko et al. 2020a; Lahoti et al. 2020; Lemougna et al. 2020), geopolymers have found useful applications not only in the construction industry but also for the immobilization of toxic waste and heavy metals, as well as coatings in various industries (Bazan et al. 2020; Jiang et al. 2020b). Currently, geopolymer composites are the most promising environmentally friendly alternative to traditional cementitious materials including OPC, because their use could significantly reduce $\mathrm{CO}_{2}$ emissions as a result of the low carbon footprint of the various raw materials from which they can be prepared (Sarmin et al. 2014; Shalbafan et al. 2016; Silva et al. 2020). These distinctive properties have allowed the development of eco-responsible construction materials from both natural minerals and industrial wastes/ 
residues, viz. geopolymer cement, mortars, and concrete with similar or even better performance properties than traditional materials. Still, despite their high compressive strength, geopolymer materials possess major weaknesses of low ductility and brittle cracking behavior. This limits their use in possible structural functions. These weaknesses are quite similar to those of other hardened inorganic mineral binders/cement such as OPC and magnesium cement (Silva et al. 2019; Bazan et al. 2020; Korniejenko et al. 2020a; Silva et al. 2020).

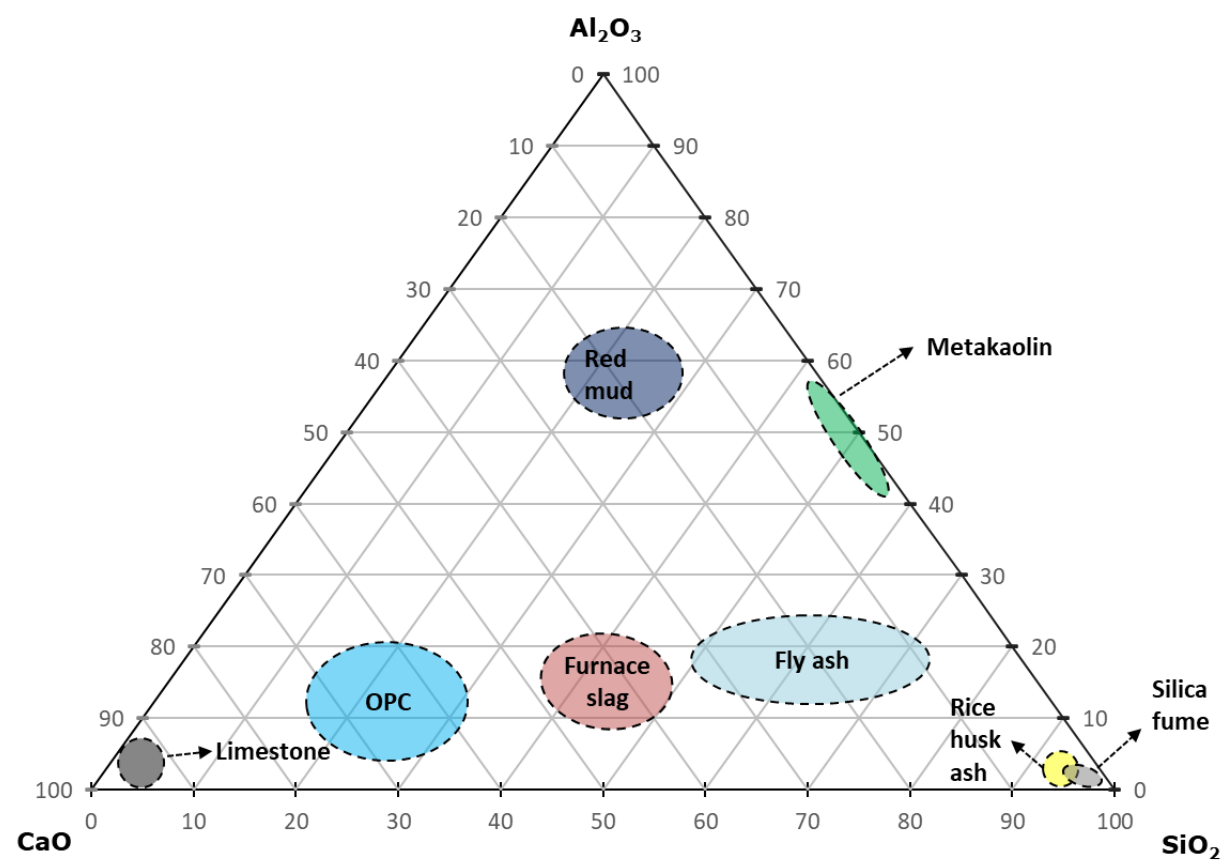

Fig. 5. Ternary phase diagram $\left(\mathrm{CaO}-\mathrm{SiO}_{2}-\mathrm{Al}_{2} \mathrm{O}_{3}\right)$ indicating major compositions (\%) of various precursors used for the production of geopolymers and alkali-activated cement compared to OPC

\section{Geopolymer-based lignocellulosic composites}

A lot of studies have been conducted to develop geopolymer composites reinforced with both natural and synthetic fibers to improve their ductility, flexural strength, and fracture toughness (Korniejenko et al. 2020a; Silva et al. 2020). Detailed reviews have been published regarding the recent advances in the production of natural fiber-reinforced materials with potential construction applications and their performance (Sarmin et al. 2014; Korniejenko et al. 2020b; Silva et al. 2019, 2020). Therefore, this review focuses on the influence of the curing conditions and activator composition, as well fiber surface treatment on the performance of lignocellulosic fiber-reinforced geopolymer composites. Tables 4, 5, 6, and 7 summarize the production parameters and mechanical properties of lignocellulosic fiber-reinforced geopolymer composites in the literature.

\section{Alkali-Activated Cement}

Alkali-activated (AA) cements are cementitious binders formed by activating aluminosilicates with highly alkaline solutions. Due to their less negative environmental impact, AA cement was adopted to substitute OPC. Besides, it is now widely accepted that AA cement has advantages over Portland cement in terms of energy cost, strength, and high-temperature resistance (Puertas and Fernández-Jiménez 2003). 
Table 4. Production Parameters and Mechanical Strength Properties of Lignocellulosic Fiber Reinforced Geopolymer Composites*

\begin{tabular}{|c|c|c|c|c|c|c|c|c|c|c|}
\hline Precursor & Activator & $\begin{array}{l}\text { Type of } \\
\text { fiber }\end{array}$ & $\begin{array}{l}\text { Fiber } \\
\text { content }\end{array}$ & $\begin{array}{c}\text { Length } \\
\text { of } \\
\text { fibers } \\
\text { (mm) } \\
\end{array}$ & $\begin{array}{l}\text { Initial } \\
\text { curing } \\
\text { details }\end{array}$ & $\begin{array}{l}\text { Type of } \\
\text { casting } \\
\text { details }\end{array}$ & $\begin{array}{c}\text { Density of } \\
\text { the } \\
\text { composite } \\
\left(\mathrm{kg} / \mathrm{m}^{3}\right) \\
\end{array}$ & $\begin{array}{l}\text { Curing } \\
\text { time } \\
\text { (Days) }\end{array}$ & $\begin{array}{l}\text { Mechanical } \\
\text { Strength } \\
(\mathrm{MPa})^{\star \star}\end{array}$ & Reference \\
\hline $\begin{array}{c}\text { Dehydro- } \\
\text { xylated } \\
\text { halloysite }\end{array}$ & $\begin{array}{c}\mathrm{NaOH} \\
+ \\
\mathrm{Na}_{2} \mathrm{SiO}_{3}\end{array}$ & Flax fiber & 10 wt\% & $\begin{array}{l}0.01- \\
0.08 \\
\mathrm{~mm}\end{array}$ & $\begin{array}{l}40^{\circ} \mathrm{C} \\
\text { for } 2 \\
\text { days }\end{array}$ & $\begin{array}{c}\text { bar- } \\
\text { shaped, } \\
120 \times 10 \\
\times 6 \mathrm{~mm}^{3}\end{array}$ & $n / a$ & 28 & FI: 70.2 & $\begin{array}{c}\text { Alzeer and } \\
\text { Mackenzie } \\
(2013)\end{array}$ \\
\hline Metakaolin & $\begin{array}{c}\mathrm{NaOH} \\
\stackrel{+}{\mathrm{Na}_{2} \mathrm{SiO}_{3}}\end{array}$ & $\begin{array}{c}\text { Cornhusk } \\
\text { Bundles }\end{array}$ & $5 \mathrm{wt} \%$ & $\mathrm{n} / \mathrm{a}$ & $\begin{array}{l}50^{\circ} \mathrm{C} \\
\text { for } 1 \\
\text { day }\end{array}$ & $\begin{array}{c}\text { rectan- } \\
\text { gular, } \\
152.4 \mathrm{~mm} \\
\times 203.2 \\
\mathrm{~mm}\end{array}$ & $\mathrm{n} / \mathrm{a}$ & 1 & FI: 8.8 & $\begin{array}{l}\text { Kriven et } \\
\text { al. (2013) }\end{array}$ \\
\hline Metakaolin & $\begin{array}{c}\mathrm{NaOH} \\
+ \\
\mathrm{Na}_{2} \mathrm{SiO}_{3} \\
\end{array}$ & $\begin{array}{l}\text { Luffa } \\
\text { fiber }\end{array}$ & $\begin{array}{l}10 \% \\
\text { (vol.) }\end{array}$ & $n / a$ & $\begin{array}{l}40^{\circ} \mathrm{C} \\
\text { for } 1 \\
\text { day } \\
\end{array}$ & $\begin{array}{c}\text { prism, } \\
160 \times 100 \\
\times 20 \mathrm{~mm}^{3} \\
\end{array}$ & $\mathrm{n} / \mathrm{a}$ & $\mathrm{n} / \mathrm{a}$ & $\begin{array}{l}\text { CM: } 31.0 \\
\text { FI: } 14.2\end{array}$ & $\begin{array}{c}\text { Alshaaer et } \\
\text { al. (2017) }\end{array}$ \\
\hline $\begin{array}{l}\text { Fly ash } \\
\text { (Class F) }\end{array}$ & $\begin{array}{c}8 \mathrm{M} \mathrm{NaOH} \\
+ \\
\mathrm{Na}_{2} \mathrm{SiO}_{3}\end{array}$ & $\begin{array}{l}\text { Cotton } \\
\text { fabric }\end{array}$ & $2.1 \mathrm{wt} \%$ & $\mathrm{n} / \mathrm{a}$ & $\begin{array}{l}105^{\circ} \mathrm{C} \\
\text { for } 3 \mathrm{~h}\end{array}$ & $\mathrm{n} / \mathrm{a}$ & $\begin{array}{c}1590 \text { to } \\
2020\end{array}$ & 28 & FI: $\sim 12.5$ & $\begin{array}{l}\text { Alomayri et } \\
\text { al. (2013a) }\end{array}$ \\
\hline $\begin{array}{l}\text { Fly ash } \\
\text { (Class F) }\end{array}$ & $\begin{array}{c}8 \mathrm{M} \mathrm{NaOH} \\
+\underset{+}{\mathrm{Na}_{2} \mathrm{SiO}_{3}}\end{array}$ & $\begin{array}{l}\text { Cotton } \\
\text { fiber }\end{array}$ & $0.5 w t \%$ & $10 \mathrm{~mm}$ & $\begin{array}{l}105^{\circ} \mathrm{C} \\
\text { for } 3 \mathrm{~h}\end{array}$ & $\begin{array}{c}\text { rectan- } \\
\text { gular, } \\
80 \times 20 \times \\
10 \mathrm{~mm}^{3}\end{array}$ & $\begin{array}{c}1800 \text { to } \\
2000\end{array}$ & 28 & FI: 11.7 & $\begin{array}{l}\text { Alomayri et } \\
\text { al. (2013b) }\end{array}$ \\
\hline $\begin{array}{l}\text { Fly ash } \\
\text { (Class F) }\end{array}$ & $\begin{array}{c}8 \mathrm{M} \mathrm{NaOH} \\
+ \\
\mathrm{Na}_{2} \mathrm{SiO}_{3}\end{array}$ & $\begin{array}{l}\text { Cotton } \\
\text { fiber }\end{array}$ & $0.5 w t \%$ & $10 \mathrm{~mm}$ & $\begin{array}{l}105^{\circ} \mathrm{C} \\
\text { for } 3 \mathrm{~h}\end{array}$ & $\begin{array}{c}\text { rectan- } \\
\text { gular, } \\
80 \times 20 \times \\
10 \mathrm{~mm}^{3}\end{array}$ & $n / a$ & 28 & CM: 48 & $\begin{array}{l}\text { Alomayri et } \\
\text { al. (2013c) }\end{array}$ \\
\hline
\end{tabular}


Table 5. Production Parameters and Mechanical Strength Properties of Lignocellulosic Fiber Reinforced Geopolymer Composites* (Contd.)

\begin{tabular}{|c|c|c|c|c|c|c|c|c|c|c|}
\hline Precursor & Activator & $\begin{array}{l}\text { Type } \\
\text { of } \\
\text { fiber }\end{array}$ & $\begin{array}{l}\text { Fiber } \\
\text { content }\end{array}$ & $\begin{array}{c}\text { Length } \\
\text { of } \\
\text { fibers } \\
(\mathrm{mm})\end{array}$ & $\begin{array}{l}\text { Initial } \\
\text { curing } \\
\text { details }\end{array}$ & $\begin{array}{l}\text { Type of } \\
\text { casting } \\
\text { details }\end{array}$ & $\begin{array}{c}\text { Density of } \\
\text { the } \\
\text { composite } \\
\left(\mathrm{kg} / \mathrm{m}^{3}\right)\end{array}$ & $\begin{array}{c}\text { Curing } \\
\text { time } \\
\text { (Days) }\end{array}$ & $\begin{array}{c}\text { Mechanic } \\
\text { al } \\
\text { Strength } \\
(\mathrm{MPa})^{\star \star}\end{array}$ & Reference \\
\hline Metakaolin & $\begin{array}{l}\mathrm{Na}_{2} \mathrm{SiO}_{3} \\
\left(\mathrm{SiO}_{2} / \mathrm{Na}_{2}\right. \\
\mathrm{O})=2.17\end{array}$ & $\begin{array}{l}\text { Sisal } \\
\text { fiber }\end{array}$ & 3 wt $\%$ & $\begin{array}{l}25 \mathrm{~mm} \\
\text { and } \\
50 \mathrm{~mm}\end{array}$ & $\begin{array}{l}55^{\circ} \mathrm{C} \\
\text { for } 1 \\
\text { day }\end{array}$ & $\begin{array}{c}\text { CM: } \\
\text { cylindrical, } \\
\text { d-50 mm, } \\
\text { h-100 mm } \\
\text { FI: bar- } \\
\text { shaped, } \\
160 \times 40 \\
\times 40 \mathrm{~mm}^{3} \\
\end{array}$ & $n / a$ & $n / a$ & $\begin{array}{l}\text { CM: } 6 \\
\text { FI: } 2.7\end{array}$ & $\begin{array}{l}\text { Correia et } \\
\text { al. (2013) }\end{array}$ \\
\hline $\begin{array}{l}\text { Fly ash } \\
\text { (Class F) }\end{array}$ & $\begin{array}{c}8 \mathrm{M} \mathrm{NaOH} \\
+ \\
\mathrm{Na}_{2} \mathrm{SiO}_{3}\end{array}$ & $\begin{array}{l}\text { Cotton } \\
\text { fabric }\end{array}$ & 8.3 wt\% & $\mathrm{n} / \mathrm{a}$ & $\begin{array}{l}80^{\circ} \mathrm{C} \\
\text { for } 1 \\
\text { day }\end{array}$ & $\mathrm{n} / \mathrm{a}$ & 1900 & 28 & $\begin{array}{l}\text { CM: 90 } \\
\text { FI: } 31.7\end{array}$ & $\begin{array}{l}\text { Alomayri et } \\
\text { al. (2014b) }\end{array}$ \\
\hline Metakaolin & $\begin{array}{l}\mathrm{Na}_{2} \mathrm{SiO}_{3} \\
\left(\mathrm{SiO}_{2} / \mathrm{Na}_{2}\right. \\
\mathrm{O})=2.17\end{array}$ & $\begin{array}{l}\text { Pine- } \\
\text { apple } \\
\text { leaf } \\
\text { fiber }\end{array}$ & 1.2 wt\% & $\begin{array}{l}25 \\
\text { and } \\
50\end{array}$ & $\begin{array}{l}55^{\circ} \mathrm{C} \\
\text { for } 1 \\
\text { day }\end{array}$ & $\begin{array}{c}\text { CM: } \\
\text { cylindrical, } \\
\text { d-50 mm, } \\
\text { h-100 mm } \\
\text { FI: bar- } \\
\text { shaped, } \\
160 \times 40 \\
\times 40 \mathrm{~mm}^{3}\end{array}$ & $\mathrm{n} / \mathrm{a}$ & $n / a$ & $\begin{array}{c}\text { CM: } 3.3 \\
\text { FI: } 2\end{array}$ & $\begin{array}{l}\text { Correia et } \\
\text { al. }(2013\end{array}$ \\
\hline $\begin{array}{l}\text { Fly ash } \\
\text { (Class F) }\end{array}$ & $\begin{array}{c}8 \mathrm{M} \mathrm{NaOH} \\
\stackrel{+}{\mathrm{Na}_{2} \mathrm{SiO}_{3}}\end{array}$ & $\begin{array}{l}\text { Cotton } \\
\text { fabric, } \\
\text { (paral- } \\
\text { lel to } \\
\text { fabric) }\end{array}$ & 8.3 wt\% & $\mathrm{n} / \mathrm{a}$ & $\begin{array}{l}80^{\circ} \mathrm{C} \\
\text { for } 1 \\
\text { day }\end{array}$ & $\mathrm{n} / \mathrm{a}$ & $\mathrm{n} / \mathrm{a}$ & 28 & $\begin{array}{c}\text { CM: 60 } \\
\text { FI: } 26\end{array}$ & $\begin{array}{l}\text { Alomayri et } \\
\text { al. (2014a) }\end{array}$ \\
\hline
\end{tabular}


Table 6. Production Parameters and Mechanical Strength Properties of Lignocellulosic Fiber Reinforced Geopolymer Composites* (Contd.)

\begin{tabular}{|c|c|c|c|c|c|c|c|c|c|c|}
\hline Precursor & Activator & $\begin{array}{l}\text { Type of } \\
\text { fiber }\end{array}$ & $\begin{array}{c}\text { Fiber } \\
\text { content }\end{array}$ & $\begin{array}{l}\text { Length } \\
\text { of } \\
\text { fibers } \\
(\mathrm{mm})\end{array}$ & $\begin{array}{c}\text { Initial } \\
\text { curing } \\
\text { (details) }\end{array}$ & $\begin{array}{l}\text { Type of } \\
\text { casting } \\
\text { (details) }\end{array}$ & $\begin{array}{c}\text { Density of } \\
\text { the com- } \\
\text { posite } \\
\left(\mathrm{kg} / \mathrm{m}^{3}\right)\end{array}$ & $\begin{array}{c}\text { Curing } \\
\text { time } \\
\text { (Days) }\end{array}$ & $\begin{array}{c}\text { Mechanical } \\
\text { Strength } \\
(\mathrm{MPa})^{\star \star}\end{array}$ & Reference \\
\hline $\begin{array}{l}\text { Fly ash } \\
\text { (Class F) }\end{array}$ & $\begin{array}{l}\mathrm{NaOH} \\
\text { solution }\end{array}$ & Sorghum & $2.0 w t \%$ & $<10$ & $\begin{array}{l}60^{\circ} \mathrm{C} \\
\text { for } 3 \mathrm{~h}\end{array}$ & $\begin{array}{l}\text { CM: cylind- } \\
\text { rical, d-35mm, } \\
\text { h-70 mm } \\
\text { FI: rectan- } \\
\text { gular, } \\
360 \times 60 \times 25 \\
\mathrm{~mm}^{3}\end{array}$ & $\sim 1500$ & 7 & $\begin{array}{c}\text { FI: } 5.4 \\
\text { CM: } 22.9\end{array}$ & $\begin{array}{l}\text { Chen et } \\
\text { al. (2014) }\end{array}$ \\
\hline $\begin{array}{l}\text { Fly ash } \\
\text { (Class F) }\end{array}$ & $\begin{array}{c}8 \mathrm{M} \mathrm{NaOH} \\
+ \\
\mathrm{Na}_{2} \mathrm{SiO}_{3} \\
\end{array}$ & $\begin{array}{l}\text { Flax } \\
\text { fabric }\end{array}$ & $4.1 w t \%$ & $n / a$ & $\begin{array}{l}60^{\circ} \mathrm{C} \\
\text { for } 1 \\
\text { day }\end{array}$ & $\mathrm{n} / \mathrm{a}$ & $\mathrm{n} / \mathrm{a}$ & 28 & $\begin{array}{l}\text { FI: } 91 \\
\text { CM: } 23\end{array}$ & $\begin{array}{l}\text { Assaedi et } \\
\text { al. (2015) }\end{array}$ \\
\hline $\begin{array}{l}\text { Fly ash and } \\
\text { metakaolin }\end{array}$ & $\begin{array}{c}10 \mathrm{M} \\
\mathrm{NaOH} \\
+ \\
\mathrm{Na}_{2} \mathrm{SiO}_{3}\end{array}$ & Wood & $10 w t \%$ & 0.7 & $\begin{array}{l}40^{\circ} \mathrm{C} \\
\text { for } 1 \\
\text { day }\end{array}$ & $\begin{array}{c}\text { CM: cubic, } \\
40 \times 40 \times 40 \\
\mathrm{~mm}^{3} \\
\text { FI: prism, } \\
40 \times 40 \times 160 \\
\mathrm{~mm}^{3} \\
\end{array}$ & $\begin{array}{l}1600 \text { to } \\
2100\end{array}$ & 28 & CM: 65 & $\begin{array}{l}\text { Duan et } \\
\text { al. (2016) }\end{array}$ \\
\hline $\begin{array}{l}\text { Fly ash } \\
\text { (Class F) }\end{array}$ & $\begin{array}{c}\mathrm{NaOH} \\
+ \\
\mathrm{Na}_{2} \mathrm{SiO}_{3} \\
\end{array}$ & $\begin{array}{l}\text { Sisal } \\
\text { fiber }\end{array}$ & $3 w t \%$ & ca. 10 & $\begin{array}{l}\text { Heat } \\
\text { cured }\end{array}$ & $\mathrm{n} / \mathrm{a}$ & $\mathrm{n} / \mathrm{a}$ & 14 & $\begin{array}{l}\text { FI: } 4.5 \\
\text { CM: } 41\end{array}$ & $\begin{array}{c}\text { Patel and Joshi } \\
\text { (2016) }\end{array}$ \\
\hline $\begin{array}{l}\text { Fly ash, } \\
\text { silica }\end{array}$ & $\begin{array}{c}16 \mathrm{M} \\
\mathrm{NaOH} \\
+\mathrm{Na}_{2} \mathrm{SiO}_{3}\end{array}$ & Coir fiber & $\begin{array}{l}0.75 \\
w t \%\end{array}$ & 25 & $\begin{array}{l}\text { Heat } \\
\text { cured }\end{array}$ & $\begin{array}{c}\text { cubic, } \\
70 \times 70 \times 70 \\
\mathrm{~mm}^{3}\end{array}$ & $\mathrm{n} / \mathrm{a}$ & 28 & CM: 51.2 & $\begin{array}{l}\text { Siddharth et } \\
\text { al. (2016) }\end{array}$ \\
\hline $\begin{array}{c}76 \% \\
\text { metakaolin, } \\
24 \% \text { silica }\end{array}$ & $\begin{array}{c}14 \mathrm{M} \\
\mathrm{NaOH} \\
+ \\
\mathrm{Na}_{2} \mathrm{SiO}_{3}\end{array}$ & Bamboo & $5 w t \%$ & $\begin{array}{c}12.5- \\
40\end{array}$ & $\begin{array}{l}20^{\circ} \mathrm{C} \\
\text { for } 28 \\
\text { days }\end{array}$ & $\begin{array}{c}\text { Cubic, } \\
50 \times 50 \times 50 \\
\mathrm{~mm}^{3}\end{array}$ & $\begin{array}{l}1550 \text { to } \\
1705\end{array}$ & 7 & $\begin{array}{l}\text { FI: } 27.6 \\
\text { CM: } 33.1\end{array}$ & Sarmin (2016) \\
\hline
\end{tabular}


Table 7. Production Parameters and Mechanical Strength Properties of Lignocellulosic Fiber Reinforced Geopolymer Composites* (Contd.)

\begin{tabular}{|c|c|c|c|c|c|c|c|c|c|c|}
\hline Precursor & Activator & $\begin{array}{l}\text { Type of } \\
\text { fiber }\end{array}$ & $\begin{array}{l}\text { Fiber } \\
\text { content }\end{array}$ & $\begin{array}{l}\text { Length } \\
\text { of } \\
\text { fibers } \\
\text { (mm) }\end{array}$ & $\begin{array}{c}\text { Initial } \\
\text { curing } \\
\text { (details) }\end{array}$ & $\begin{array}{l}\text { Type of } \\
\text { casting } \\
\text { (details) }\end{array}$ & $\begin{array}{c}\text { Density of } \\
\text { the } \\
\text { composite } \\
\left(\mathrm{kg} / \mathrm{m}^{3}\right)\end{array}$ & $\begin{array}{c}\text { Curing } \\
\text { time } \\
\text { (Days) }\end{array}$ & $\begin{array}{c}\text { Mechanical } \\
\text { Strength } \\
(\mathrm{MPa})^{\star \star}\end{array}$ & Reference \\
\hline $\begin{array}{l}\text { Fly ash } \\
\text { (Class F) }\end{array}$ & $\begin{array}{c}\mathrm{NaOH} \\
+ \\
\mathrm{Na}_{2} \mathrm{SiO}_{3} \\
\end{array}$ & $\begin{array}{c}\text { Pineapp } \\
\text { le leaf } \\
\text { fiber }\end{array}$ & $1.2 \mathrm{wt} \%$ & ca. 50 & $\begin{array}{l}60^{\circ} \mathrm{C} \\
\text { for } 1 \\
\text { hour }\end{array}$ & $\mathrm{n} / \mathrm{a}$ & $\begin{array}{c}1990 \text { to } \\
2020\end{array}$ & 28 & $\begin{array}{c}\text { FI: } 7.1 \\
\text { CM: } 58.2\end{array}$ & Amalia et al. (2017a) \\
\hline $\begin{array}{l}\text { Fly ash } \\
\text { (Class F) }\end{array}$ & \multirow{4}{*}{$\begin{array}{c}8 \mathrm{M} \mathrm{NaOH} \\
+\underset{+}{\mathrm{Na}_{2} \mathrm{SiO}_{3}}\end{array}$} & $\begin{array}{l}\text { Cotton } \\
\text { fiber }\end{array}$ & $1 \mathrm{wt} \%$ & 30 & \multirow{4}{*}{$\begin{array}{l}75^{\circ} \mathrm{C} \\
\text { for } 1 \\
\text { day }\end{array}$} & \multirow{4}{*}{$\mathrm{n} / \mathrm{a}$} & $\mathrm{n} / \mathrm{a}$ & 28 & $\begin{array}{c}\text { FI: } 5.8 \\
\text { CM: } 28.4\end{array}$ & \multirow{4}{*}{$\begin{array}{c}\text { Korniejenko et } \\
\text { al. (2016) }\end{array}$} \\
\hline $\begin{array}{l}\text { Fly ash } \\
\text { (Class F) }\end{array}$ & & $\begin{array}{l}\text { Sisal } \\
\text { fiber, }\end{array}$ & $1 \mathrm{wt} \%$ & 3 & & & $n / a$ & 28 & $\begin{array}{c}\text { FI: } 5.9 \\
\text { CM: } 25.2\end{array}$ & \\
\hline $\begin{array}{c}\text { Fly ash } \\
\text { (Class F) }\end{array}$ & & $\begin{array}{l}\text { Coir } \\
\text { fiber, }\end{array}$ & $1 \mathrm{wt} \%$ & 3 & & & $\mathrm{n} / \mathrm{a}$ & 28 & $\begin{array}{c}\text { FI: } 5.2 \\
\text { CM: } 31.4\end{array}$ & \\
\hline $\begin{array}{l}\text { Fly ash } \\
\text { (Class F) }\end{array}$ & & $\begin{array}{l}\text { Raffia } \\
\text { fiber }\end{array}$ & $1 \mathrm{wt} \%$ & 3 & & & $\mathrm{n} / \mathrm{a}$ & 28 & $\begin{array}{c}\text { FI: } 3.0 \\
\text { CM: } 13.7\end{array}$ & \\
\hline $\begin{array}{l}\text { Fly ash } \\
\text { (Class F) }\end{array}$ & $\begin{array}{c}\mathrm{NaOH} \\
\stackrel{+}{\mathrm{Na}_{2} \mathrm{SiO}_{3}}\end{array}$ & $\begin{array}{l}\text { Coconut } \\
\text { trunk } \\
\text { fiber }\end{array}$ & $0.5 w t \%$ & $\begin{array}{c}30 \text { to } \\
50\end{array}$ & $\begin{array}{l}70^{\circ} \mathrm{C} \\
\text { for } 1 \\
\text { hour }\end{array}$ & $\mathrm{n} / \mathrm{a}$ & $\mathrm{n} / \mathrm{a}$ & 28 & $\begin{array}{l}\text { FI: } 7.64 \\
\text { CM: } 89.4\end{array}$ & Amalia et al. (2017b) \\
\hline $\begin{array}{l}\text { Fly ash } \\
\text { (Class F) }\end{array}$ & $\begin{array}{c}12 \mathrm{M} \\
\mathrm{NaOH} \\
+ \\
\mathrm{Na}_{2} \mathrm{SiO}_{3}\end{array}$ & $\begin{array}{l}\text { Abaca } \\
\text { fiber }\end{array}$ & $8 w t \%$ & $\begin{array}{c}0.1 \text { to } \\
0.2\end{array}$ & $\begin{array}{l}75^{\circ} \mathrm{C} \\
\text { for } 1 \\
\text { day }\end{array}$ & $\begin{array}{c}\text { CM: } \\
\text { cubic } \\
50 \times 50 \\
\times 50 \mathrm{~mm}^{3} \\
\text { FI: prism, } \\
50 \times 50 \\
\times 180 \\
\mathrm{~mm}^{3}\end{array}$ & $\mathrm{n} / \mathrm{a}$ & 28 & $\begin{array}{l}\text { FI: } 27 \\
\text { CM: } 50\end{array}$ & Malenab et al. (2017) \\
\hline
\end{tabular}


Differences between AA cements and geopolymers consist of raw materials composition, the formation chemistry and properties of the final product (Waldmann and Thapa 2018). In particular, precursors of AA cement are usually high-calcium aluminosilicates (blast furnace slag and in some cases fly ash with high amounts of calcium), while geopolymers are produced by the activation of raw materials with low calcium content such as fly ash (Class F) and metakaolin (Li et al. 2010). Figure 6 shows an illustration of the classification of various cementitious products based on the major cation content. Another difference is related to the $\mathrm{pH}$ of the activator. In the case of geopolymers, the $\mathrm{pH}$ is slightly alkaline, while for AA cement it is considerably higher. In addition, AA cement has higher mechanical strength but lacks long-term durability compared to geopolymers (Davidovits 2017). More research needs to be undertaken regarding the specific network structure of the mineral phases (Li et al. 2010). This section covers only composites obtained from calcium-rich raw precursors of AA cement and various types of lignocellulosic fibers.

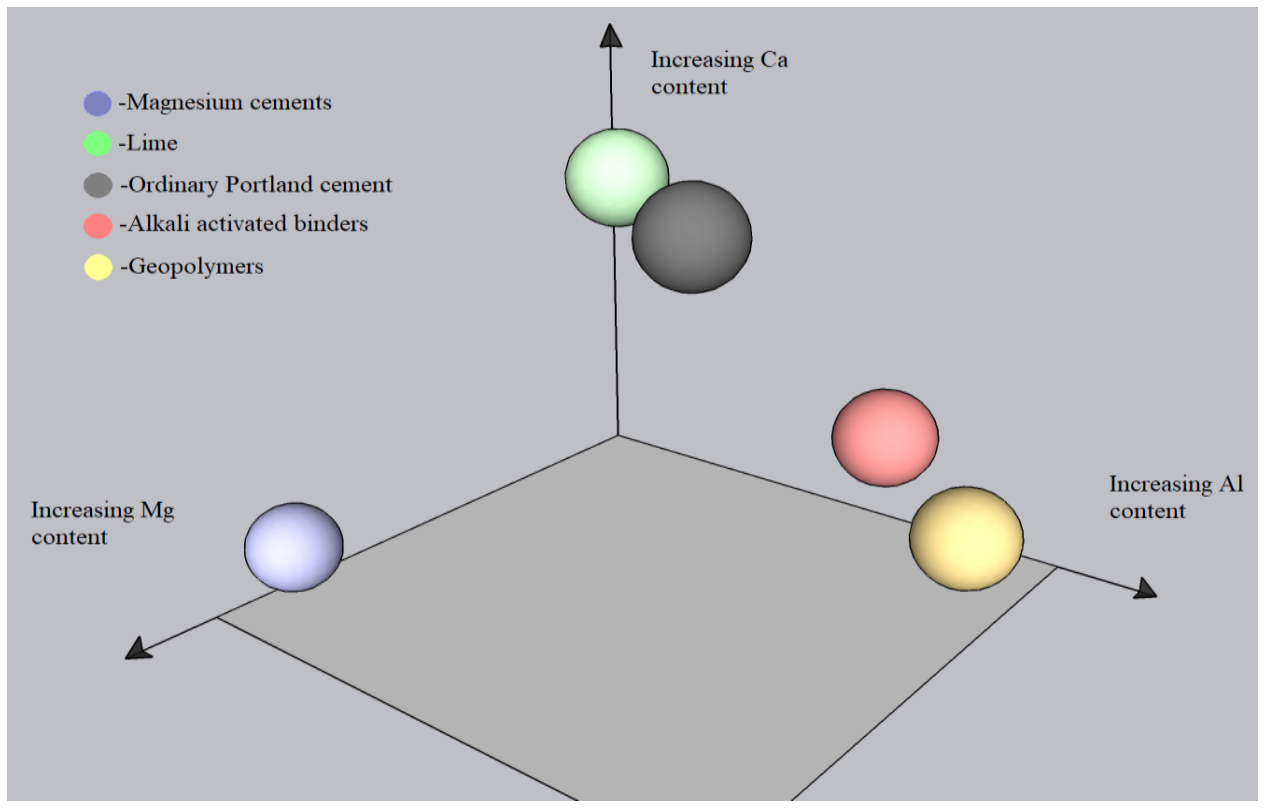

Fig. 6. Classification of different subsets of various non-conventional cementitious materials in comparison to OPC

\section{Alkali activated (AA) cement - lignocellulosic composites}

Alike other cementitious products, the properties of AA cement composites were in most cases improved when natural fibers were incorporated. Generally, the addition of a small amount of fibers ( 1 to $3 \mathrm{wt} \%$ ) positively influenced mechanical properties, density (lower), and other physical characteristics such as water sorption. Poletanovic et al. (2020) studied the effect of hemp fibers in AA cement. Their raw materials for two formulations consisted of fly ash and a mixture of fly ash with ground granulated blast furnace slag (GGBFS). In general, the addition of fibers did not have a great effect on the composites' mechanical properties, but it increased its energy absorption capacity and thus toughness. With the increment of the fiber proportion, the density decreased, while water absorption increased. Detailed information on raw materials and production parameters can be found in Table 8. 
Table 8. Production Parameters and Mechanical Strength Properties of Lignocellulosic Fiber Reinforced with AA Cement Composites

\begin{tabular}{|c|c|c|c|c|c|c|c|c|c|c|}
\hline Precursor & Activator & $\begin{array}{c}\text { Type } \\
\text { of fiber }\end{array}$ & $\begin{array}{c}\text { Amount } \\
\text { of fibers } \\
(\%)\end{array}$ & $\begin{array}{c}\text { Length } \\
\text { of } \\
\text { fibers } \\
\text { (mm) }\end{array}$ & $\begin{array}{l}\text { Initial } \\
\text { curing } \\
\text { details }\end{array}$ & $\begin{array}{l}\text { Type of } \\
\text { casting }\end{array}$ & $\begin{array}{l}\text { Density of the } \\
\text { composite } \\
\left(\mathrm{kg} / \mathrm{m}^{3}\right)\end{array}$ & $\begin{array}{l}\text { Curing } \\
\text { time } \\
\text { (Days) }\end{array}$ & $\begin{array}{l}\text { Maximal } \\
\text { strength } \\
(\mathrm{MPa})^{\star}\end{array}$ & Reference \\
\hline Furnace slag & $\mathrm{NaOH}$ & $\begin{array}{l}\text { Wood } \\
\text { fibers }\end{array}$ & $\begin{array}{l}3.5,6.3 \\
8.3,10.1\end{array}$ & $\begin{array}{l}0.06 \text { to } \\
8 \mathrm{~mm}\end{array}$ & $\begin{array}{l}60^{\circ} \mathrm{C} \\
\text { for } 1 \\
\text { day }\end{array}$ & $\begin{array}{c}\text { CM: cubic } \\
40 \times 40 \times 40 \\
\mathrm{~mm}^{3} \\
\text { FI; Metallic } \\
\text { prism, } 4 \times 4 \times \\
16 \mathrm{~mm}^{3} \\
\end{array}$ & 1000 to 1800 & 28 & $\begin{array}{l}\mathbf{F I} ; 10.1 \\
\mathbf{C M}: ~ 21\end{array}$ & $\begin{array}{l}\text { Kielè et al. } \\
2020\end{array}$ \\
\hline Furnace slag & \multirow{3}{*}{$\begin{array}{c}\mathrm{KOH}, \\
\stackrel{\mathrm{NaOH}}{+} \\
\stackrel{+}{\mathrm{Na}_{2} \mathrm{SiO}_{3}}\end{array}$} & $\begin{array}{l}\text { Wheat } \\
\text { Straw }\end{array}$ & 1 & 20 to 30 & \multirow{3}{*}{$\begin{array}{l}20^{\circ} \mathrm{C} \\
\text { for } 1 \\
\text { day }\end{array}$} & \multirow{3}{*}{$\begin{array}{c}\text { CM: cubic } \\
40 \times 40 \times 80 \\
\mathrm{~mm}^{3} \\
\text { FI; Metallic } \\
\text { prism, } 4 \times 4 \times \\
16 \mathrm{~mm}^{3}\end{array}$} & \multirow{3}{*}{$\mathrm{n} / \mathrm{a}$} & \multirow{3}{*}{7,28} & $\begin{array}{l}\text { FL: } 12.4 \\
\text { CM:108.4 }\end{array}$ & Zhu et al. 2019 \\
\hline Furnace slag & & $\begin{array}{l}\text { Rice } \\
\text { straw }\end{array}$ & 1 & 20 to 30 & & & & & $\begin{array}{c}\text { FI: } 7.8 \\
\text { CM:81.6 }\end{array}$ & Zhu et al. 2019 \\
\hline Furnace slag & & $\begin{array}{l}\text { Corn } \\
\text { stalk }\end{array}$ & 1 & 20 to 30 & & & & & $\begin{array}{c}\text { FI: } 9.6 \\
\text { CM: } 108.1\end{array}$ & Zhu et al. 2019 \\
\hline $\begin{array}{l}\text { Furnace slag } \\
\text { and Ca-rich } \\
\text { fly ash }\end{array}$ & $\mathrm{Na}_{2} \mathrm{SiO}_{3}$ & Hemp & $0.5,1$ & 10 & $\begin{array}{l}60- \\
80^{\circ} \mathrm{C} \\
\text { for } 1 \\
\text { day }\end{array}$ & $\begin{array}{c}\text { CM: cubic } \\
40 \times 40 \times 40 \\
\mathrm{~mm}^{3} \\
\text { FI; Metallic } \\
\text { prism, } \\
4 \times 4 \times 16 \\
\mathrm{~mm}^{3}\end{array}$ & 1800 to 2000 & 28 & $\begin{array}{l}\text { FI: } 6.39 \\
\text { CM: 32 }\end{array}$ & $\begin{array}{c}\text { Poletanovic et } \\
\text { al. } 2020\end{array}$ \\
\hline Furnace slag & $\begin{array}{c}4.8 \mathrm{M} \\
\mathrm{NaOH} \\
+ \\
6.5 \mathrm{M} \\
\mathrm{Na}_{2} \mathrm{SiO}_{3}\end{array}$ & $\begin{array}{l}\text { Rice } \\
\text { straw }\end{array}$ & $1,2,3$ & 15 to 20 & $\begin{array}{l}20^{\circ} \mathrm{C} \\
\text { for } 1 \\
\text { day }\end{array}$ & $\begin{array}{c}\text { CM: cubic } \\
50 \times 50 \times 50 \\
\mathrm{~mm}^{3} \\
\text { FI; Metallic } \\
\text { prism, } \\
4 \times 4 \times 16 \mathrm{~mm}\end{array}$ & 1700 to 1900 & 14,28 & $\begin{array}{l}\text { FI: } 6.2 \\
\text { CM: } 45\end{array}$ & $\begin{array}{c}\text { Nguyen and } \\
\text { Mangat } 2020\end{array}$ \\
\hline
\end{tabular}


Zhu et al. (2019) produced AA cement composites incorporating $1 \mathrm{wt} \%$ of three types of fibers (wheat straw, straw, and corn stalk). Wheat straw-AA cement composites reached the highest strength because of the more homogenous distribution of these fibers compared to others. The strength values were equivalent to those of OPCs. Furthermore, the composites maintain their flexural strength even at extreme temperatures (200 $400{ }^{\circ} \mathrm{C}$ ). In a similar approach, small amounts (1 to $3 \mathrm{wt} \%$ ) of rice husk were used to prepare AA cement composites (Van Nguyen and Mangat 2020). The embodied fibers improved mechanical performance and physical properties such as drying shrinkage and water absorption. The authors attributed the change of these properties to the reduced porosity because of the reduction in liquid activator/binder ratio caused by the hydrophilic nature of rice straw and the internal curing induced by the moisture held in the straw. In contrast with other studies, the water absorption of composites was reduced compared to pure AA cement concrete. The authors attributed this finding to the reduction in "bleeding" as fibers increase mix stiffness and reduce the settlement of aggregates (sand).

AA cement composites were produced containing various amounts (3.5 to $10.1 \mathrm{wt} \%$, higher than other studies) of wood shavings (Kielè et al. 2020). Flexural strength of the composites containing up to $6.3 \mathrm{wt} \%$ shavings nearly doubled compared to that of pure AA cement concrete. Further addition of wood particles worsened the mechanical properties. Increasing contents of fibers in the composites reduced the thermal conductivity up to $84 \%$ compared to reference specimens. A content of up to $6.3 \mathrm{wt} \%$ wood shavings was recommended to achieve the balance between thermal and structural properties.

\section{Influence of Production Parameters on the Performance of Geopolymer- and Alkali-Activated Cement-Bonded Lignocellulosic Composites}

The foregoing has clearly shown that the performance of both geopolymer- and alkali-activated cement-bonded lignocellulosic composites depend on the production parameters, most especially the raw materials and on the precursors, activators, and curing conditions as well as the type of surface treatment of the lignocellulosic aggregate.

\section{Precursors, activators, and curing conditions}

The curing of freshly prepared geopolymer concrete is of critical importance in the entire geopolymerization process. Hence, proper curing has a positive effect on the final properties of the geopolymer materials (Patil et al. 2014; Yaprak et al. 2019). The preparation of a geopolymer composite involves the addition of an activator solution, which comprises of a chemical base $(\mathrm{NaOH}$ or $\mathrm{KOH})$, water glass (aqueous alkali-silicates $\mathrm{SiO}_{2}: \mathrm{M}_{2} \mathrm{O}$, where $\mathrm{M}=\mathrm{Na}$ or $\mathrm{K}$ ), and water, to the solid materials (i.e., precursor and/or aggregates). These are mixed according to a prescribed mixing scheme to form a paste, which is then placed in molds of specific dimensions. The cast pastes in the mold are then covered or sealed with a plastic film/sheet and cured at ambient temperatures, or a specified temperature for a certain period. At ambient temperatures, however, the reaction of the geopolymer precursors such as fly ash is very slow and the resulting geopolymers correspondingly show a slower setting and strength development (Patil et al. 2014; Azevedo et al. 2019). Previous studies (Tables 4, 5, 6, and 7) have shown, that higher temperatures increase the reactivity of alumino-silicate phases in the geopolymer precursors. Therefore, they are generally cured at elevated temperatures between 40 and $90{ }^{\circ} \mathrm{C}$ but can also be cured at a higher temperature of $105{ }^{\circ} \mathrm{C}$ for a short duration.

In addition to the curing conditions, the type and composition of the alkaline activator are crucial for the material properties, since they contribute to the formation of 
the structures in geopolymers during the polycondensation process (Van Jaarsveld et al. 2002; Shalbafan et al. 2016). Currently, there is a dearth of studies on the influence of curing conditions (i.e., curing duration and curing temperature) and activator solution composition on the strength performance of geopolymer composites from different types of precursors. Such information, however, is important because geopolymers exhibit a wide range of properties and characteristics (Heah et al. 2011; Rashad 2013). The precursor/alkaline liquid ratio is a governing factor in the activation process for AA cements. Almost all of the aforementioned studies utilized Ca-rich blast furnace slag as a precursor. The higher amount of $\mathrm{CaO}$ in the blast furnace can enhance the mechanical performance of AA cement ( $\mathrm{Li}$ et al. 2017). In the systems with higher $\mathrm{CaO}$ contents, the general trend has been that a higher $\mathrm{Si} / \mathrm{Al}$ ratio (>2.5) leads to a lower strength, e.g., an $\mathrm{Si} / \mathrm{Al}$ ratio of 1.9 led to higher strength (Li et al. 2017). Concerning the activator, higher strength was obtained when a mixture of sodium hydroxide and sodium silicate (added as an aqueous solution called "water glass") at an optimal $\mathrm{SiO}_{2} / \mathrm{Na}_{2} \mathrm{O}$ ratio was used instead of sodium hydroxide alone (Živica 2007, Aydin and Baradan 2014), whereas potassium silicate was reported to be more effective than sodium silicate (Zhu et al. 2019). The water glass modulus (ratio of $\mathrm{SiO}_{2}$ to $\mathrm{M}_{2} \mathrm{O}$ ) and alkali dosage are other key factors for the hydration of AA cement. Higher flexural strength was achieved using a lower water glass modulus (Zhu et al. 2019).

\section{Influence of the lignocellulosic fiber treatment and compatibility}

Empirical evidence has shown that the natural fibers are less compatible with geopolymer matrix in terms of interfacial bonding than their inorganic synthetic counterparts such as glass or carbon fibers (Korniejenko et al. 2016). This implies that surface modification of the natural fibers may essentially improve the properties of the reinforced geopolymer composites (Malenab et al. 2017). Only a few studies, however, have been carried out to assess the effect of surface modification on the fiber-matrix interfacial interaction and compatibility of lignocellulose materials with geopolymer. One study investigated the effect of alkali-pretreatment using $2 \mathrm{M} \mathrm{NaOH}$ solution on the mechanical properties of sweet sorghum fiber-reinforced fly-ash-based geopolymer. The pre-treatment induced a significant increase in unconfined compressive strength, the splitting tensile, and flexural strengths as well as the post-peak toughness with fiber content up to an optimum level of $2 \mathrm{wt} \%$ compared to respective composites without alkaline pretreatment (Chen et al. 2014). The chemical treatments of abaca fibers with sodium hydroxide $(6 \%$ by wt. $\mathrm{NaOH}$ solution for $48 \mathrm{~h})$ and aluminum salt $\left(\mathrm{Al}_{2}\left(\mathrm{SO}_{4}\right)_{3}\right.$ solution for $12 \mathrm{~h}$ ) revealed that the highest tensile strength among the treated fibers was achieved after soaking the abaca fibers in the latter solution and adjusting the $\mathrm{pH}$ to 6 (Malenab et al. 2017). The improvement of tensile strength is partly attributed to the removal of lignin, pectin, and hemicelluloses, and, partly, the roughening of the fiber surface due to the deposition of aluminum hydroxide $\left(\mathrm{Al}(\mathrm{OH})_{3}\right)$. The interconnection between the geopolymer matrix and abaca fibers is thus improved, while the deposition of insoluble aluminum hydroxide protects the fibers from disintegration by the alkaline geopolymer matrix (Malenab et al. 2017).

The evaluation of the compatibility of metakaolin-based geopolymer paste with 15 different (wood and non-wood) plant fibers revealed a good interaction. No notable differences were found in the inhibitory effects of the fibers (Tan et al. 2019). Ye et al. (2018) studied the influence of the common chemical composition of natural fibers viz. cellulose, hemicelluloses, and lignin, on geopolymer properties and fiber-matrix 
compatibility. Increasing the hemicelluloses content above $5 \mathrm{wt} \%$ lowered the degree of geopolymerization. The authors attributed this retarding effect to the presence of carboxylic acid moieties (Ye et al. 2018); these are present in glucuronic side-chains or may be generated by saponification of acetyl groups in hemicelluloses.

\section{CONCLUDING STATEMENTS}

1. In recent years, considerable progress has been made in the field of inorganically bonded lignocellulosic composites. Depending on the field of application and the desired characteristics of the final products, various points should be taken into consideration to come to the best possible solution.

2. Lime-lignocellulosic composites are generally low-strength materials compared to composites of conventional ordinary Portland cement; therefore, their application is intended for non-load-bearing and interior parts as well as insulation walls of buildings. Still, they have a promising future as sustainable alternatives in construction, owing to their low embodied energy, as well as their compatibility with a wide range of additives along with being tailorable for diverse applications. Lime enables the production of composites with high moisture buffer capacity by mixing biotic and hydrophilic porous materials with a high breathability matrix such as hydraulic lime. A wide variety of fibers can be incorporated, depending on the application. For improved insulation and moisture behavior rather than the mechanical performance of the composites, a preferable combination would be the mixture of hydrated lime with pith-containing lignocellulosic materials. Pith is a porous low-density spongy tissue with a microstructure that makes it interesting for certain building applications. Combining the permeable hydraulic lime binder with crushed vegetal pith, could result in a lightweight, humidity regulating, and insulating material.

3. Magnesium cement-lignocellulosic composites are carbon neutral and generally possess numerous advantageous properties. These include resistance to fire, chemicals, and temperature as well as low shrinkage and creep. They are easy to manufacture without the use of special equipment and high-energy input. The rapid fast curing nature of magnesium phosphate cement (MPC) and magnesium oxychloride cement (MOC) composites make them well suited for rapid repair/ and construction operations such as prefabrication. They allow for shorter compression time at temperatures close to ambient (near room) temperatures to yield materials having a wide range of functional properties. An interesting feature of MPC and MOC is their ability to accommodate and encapsulate materials. This feature can as well be exploited in the upcycling of out-of-service biocide-treated wood wastes. Magnesium oxysulfate cement (MOSC) and magnesium silicate cement (MSC) lack adequate mechanical strength for structural application. They are, however, more resistant to weathering and moisture than MPC and MOC and could therefore be used in lightweight non-structural applications where sound-, fire-, and water-resistance as well as thermal insulation properties are required.

4. Alkali-activated (AA) cements and geopolymer based-lignocellulosic composites have gained attention due to their high mechanical strength. They can be produced from a wide range of natural minerals or industrial byproducts and also show great potential 
in terms of performance properties for application in several fields. Still, the arguable long-term durability of AA cements due to efflorescence and their brittleness raise the question of whether they should be used on a large scale and in exterior environments.

5. The main advantages of geopolymer materials include chemical stability, high compressive strength, low shrinkage, and resistance to corrosive environments. Additionally, geopolymer materials are non-combustible up to very high temperatures $\left(1300{ }^{\circ} \mathrm{C}\right)$, which implies that anything it encapsulates is well protected in hightemperature environments. This feature can be exploited in applications that require high strength properties achievable by the inclusion of lignocellulosic fibers and high retention of strength after exposure to high temperatures. Similar to the MPC and MOC, geopolymers possess the capacity to accommodate a high waste loading, which can also be applied in the upcycling of large volumes of treated wood wastes reaching their end-of-life yearly. The main advantage of such composites is that the biocides are both physically encapsulated and often chemically immobilized. In addition, the composite products are fire-resistant, and therefore, unlike products based on organic polymer binders, hardly emit any harmful gases in the event/presence of fire.

6. The variability in performance properties of non-conventional mineral binder-bonded lignocellulosic composites is related to the manufacturing parameters. Consequently, there is an extensive need for research to optimize the manufacturing process parameters and thus improve their performance characteristics. Much is left to be understood about the influence of various production parameters on the mechanical properties of lime-based materials, especially in flexion. Future work should focus on improving the moisture stability of magnesium-based lignocellulosic composites from MPC and MOC, while enhancing the mechanical strength of MOSC and MSC materials is equally important. AA materials require further understanding to come to a clear conclusion regarding factors influencing the long-term performance of the cementitious matrix. For geopolymer-bonded lignocellulosic materials, there is also a significant need for research to optimize the production parameters, i.e., the precursor type, activator composition, their ratio, and curing conditions to improve performance. In addition, the improvement of fiber-matrix interfacial bonding and the effect of various fiber surface modifications on the mechanical as well as other performance (i.e., physical and water-related) properties of these inorganic mineral binder-bonded lignocellulosic materials requires further elucidation.

\section{ACKNOWLEDGMENTS}

Emmanuel Uchechukwu Opara and Aldi Kuqo are grateful for the support of the German Academic Exchange Service (DAAD).

\section{REFERENCES CITED}

Abdellatef, Y., Khan, M. A., Khan, A., Alam, M. I., and Kavgic, M. (2020).

"Mechanical, thermal, and moisture buffering properties of novel insulating hemp- 
lime composite building materials," Materials 13(21), 5000. DOI:

10.3390/ma13215000

Ahmad, M. R., Chen, B., Oderji, S. Y., and Mohsan, M. (2018). "Development of a new bio-composite for building insulation and structural purpose using corn stalk and magnesium phosphate cement; physical, mechanical, thermal and hygric evaluation," Energy and Buildings 73, 719-733. DOI: 10.1016/j.enbuild.2018.06.007

Ahmad, M. R., and Chen, B. (2020). "Microstructural characterization of basalt fiber reinforced magnesium phosphate cement supplemented by silica fume," Construction and Building Materials 237, 117795. DOI: 10.1016/j.conbuildmat.2019.117795

Alomayri, T., Shaikh, F. U. A., and Low, I. M. (2013a). "Thermal and mechanical properties of cotton fabric-reinforced geopolymer composites," Journal of Materials Science 48(19), 6746-6752. DOI: 10.1007/s10853-013-7479-2

Alomayri, T., Shaikh, F. U. A., and Low, I. M. (2013b). "Characterisation of cotton fibrereinforced geopolymer composites," Composites Part B: Engineering 50, 1-6.

DOI: 10.1016/j.compositesb.2013.01.013

Alomayri, T., and Low, I. M. (2013c). "Synthesis and characterization of mechanical properties in cotton fiber-reinforced geopolymer composites," Journal of Asian Ceramic Societies 1(1), 30-34. DOI: 10.1016/j.jascer.2013.01.002

Alomayri, T., Shaikh, F. U. A., and Low, I. M. (2014a). "Effect of fabric orientation on mechanical properties of cotton fabric reinforced geopolymer composites," Materials and Design 57, 360-365. DOI: 10.1016/j.matdes.2014.01.036

Alomayri, T., Shaikh, F. U. A., and Low, I. M. (2014b). "Synthesis and mechanical properties of cotton fabric reinforced geopolymer composites," Composites Part B: Engineering 60, 36-42. DOI: 10.1016/j.compositesb.2013.12.036

Alshaaer, M., Mallouh, S. A., Al-Kafawein, J., Al-Faiyz, Y., Fahmy, T., Kallel, A., and Rocha, F. (2017). "Fabrication, microstructural and mechanical characterization of Luffa cylindrical fibre-reinforced geopolymer composite," Applied Clay Science 143, 125-133. DOI: 10.1016/j.clay.2017.03.030

Alzeer, M., and MacKenzie, K. (2013). "Synthesis and mechanical properties of novel composites of inorganic polymers (geopolymers) with unidirectional natural flax fibres (Phormium tenax)," Applied Clay Science 75-76, 148-152. DOI: 10.1016/j.clay.2013.03.010

Amalia, N., Hidayatullah, S., and Subaer, N. (2017a). "The mechanical properties and microstructure characters of hybrid composite geopolymers-pineapple fiber leaves (PFL)," IOP Con,ference Series: Materials Science and Engineering 180, 012012. DOI: 10.1088/1757-899X/180/1/012012

Amalia, F., Akifah, N., and Subaer, N. (2017b). "Development of coconut trunk fiber geopolymer hybrid composite for structural engineering materials," IOP Conference Series: Materials Science and Engineering 180, 012014. DOI: 10.1088/1757899X/180/1/012014

Amiandamhen, S. O., Meincken, M., and Tyhoda, L. (2016). "Magnesium based phosphate cement binder for composite panels: a response surface methodology for optimisation of processing variables in boards produced from agricultural and wood processing industrial residues," Industrial Crops and Products 94, 746-754. DOI: 10.1016/j.indcrop.2016.09.051

Amiandamhen, S. O., Montecuccoli, Z., Meincken, M., Barbu, M. C., and Tyhoda, L. (2017). "Phosphate bonded wood composite products from invasive acacia trees 
occurring on the Cape Coastal Plains of South Africa," European Journal of Wood and Wood Products. DOI: 10.1007/s00107-017-1191-x

Amiandamhen, S. O., Meincken, M., and Tyhoda, L. (2019). "Phosphate bonded natural fibre composites: A state of the art assessment," SN Applied Sciences 1(8), 910. DOI: $10.1007 / \mathrm{s} 42452-019-0910-9$

Arizzi, A., Brümmer, M., Martín-Sanchez, I., Cultrone, G., and Viles, H. (2015). "The influence of the type of lime on the hygric behaviour and bio-receptivity of hemp lime composites used for rendering applications in sustainable new construction and repair works," PLOS ONE 10(5), e0125520. DOI: 10.1371/journal.pone.0125520

Assaedi, H., Alomayri, T., Shaikh, F. U. A., and Low, I. (2015). "Characterisation of mechanical and thermal properties in flax fabric reinforced geopolymer composites," Journal of Advanced Ceramics 4(4), 272-281. DOI: 10.1007/s40145-015-0161-1

Aydin, S., and Baradan, B. (2014). "Effect of activator type and content on properties of alkali-activated slag mortars," Composites Part B: Engineering 57, 166-172.

DOI: 10.1016/j.compositesb.2013.10.001

Azevedo, A. G. S., Strecker, K., Barros, L.A., Tonholo, L.F., and Lombardi, C.T. (2019). "Effect of curing temperature, activator solution composition and particle size in Brazilian fly-ash based geopolymer production," Materials Research 22(suppl 1), e20180842. DOI: 10.1590/1980-5373-mr-2018-0842

Bahrami, M., Shalbafan, A., and Welling, J. (2019a). "Development of plywood using geopolymer as binder: Effect of silica fume on the plywood and binder characteristics," European Journal of Wood and Wood Products 77, 981-994. DOI: 10.1007/s00107-019-01462-3

Barnat-Hunek, D., Smarzewski, P., and Fic, S. (2015). "Mechanical and thermal properties of hemp-lime composites," Composites Theory and Practice 15(1), 21-27. https://www.researchgate.net/publication/282779133_MECHANICAL_AND_THER MAL_PROPERTIES_OF_HEMP-LIME_COMPOSITES [accessed October 20, 2020]

Bazan, P., Kozub, B., Łach, M., and Korniejenko, K. (2020). "Evaluation of hybrid melamine and steel fiber reinforced geopolymers composites," Materials 13(23), 5548. DOI: $10.3390 / \mathrm{ma} 13235548$

Badagliacco, D., Megna, B., and Valenza, A. (2020). "Induced modification of flexural toughness of natural hydraulic lime based mortars by addition of giant reed fibers," Case Studies in Construction Materials 13, e00425. DOI: 10.1016/j.cscm.2020.e00425

Belakroum, R., Gherfi, A., Kadja, M., Maalouf, C., Lachi, M., El Wakil, N., and Mai, T. H. (2018). "Design and properties of a new sustainable construction material based on date palm fibers and lime," Construction and Building Materials 184, 330-343. DOI: 10.1016/j.conbuildmat.2018.06.196

Benaimeche, O., Carpinteri, A., Mellas, M., Ronchei, C., Scorza, D., and Vantadori, S. (2018). "The influence of date palm mesh fibre reinforcement on flexural and fracture behaviour of a cement-based mortar," Composites Part B: Engineering 152, 292-299. DOI: 10.1016/j.compositesb.2018.07.017

Billong, N., Melo, U. C., Kamseu, E., Kinuthia J. M., and Njopwouo, D. (2011). "Improving hydraulic properties of lime-rice husk ash (RHA) binders with metakaolin (MK)," Construction and Building Materials 25(4), 2157-2161. DOI: 10.1016/j.conbuildmat.2010.11.013 
Bogoeva-Gaceva, G., Avella, M., Malinconico, M., Buzarovska, A., Grozdanov, A., Gentile, G., and Errico, M. E. (2007). "Natural fiber eco-composites," Polymer Composites 28(1), 98-107. DOI: 10.1002/pc.20270

Brzyski, P., Barnat-Hunek, D., Fic, S., and Szeląg, M. (2017). "Hydrophobization of lime composites with lignocellulosic raw materials from flax," Journal of Natural Fibers 1-12. DOI: 10.1080/15440478.2016.1250024

Camargo, M. M, Eyerusalem, A. T., Roether, J. A., Redda, D. T., and Boccaccini, A. R. (2020). "A review on natural fiber-reinforced geopolymer and cement-based composites," Materials 13(20), 4603. DOI: 10.3390/ma13204603

Carran, D., Hughes, J., Leslie, A., and Kennedy, C. (2012). "A short history of the use of lime as a building material beyond Europe and North America," International Journal of Architectural Heritage 6(2), 117-146. DOI: 10.1080/15583058.2010.511694

Chen, X., and $\mathrm{Wu}, \mathrm{S}$. (2013). "Influence of water-to-cement ratio and curing period on pore structure of cement mortar," Construction and Building Materials 38, 804-812. DOI: 10.1016/j.conbuildmat.2012.09.058

Chen, R., Ahmari, S., and Zhang, L. (2014). "Utilization of sweet sorghum fiber to reinforce fly ash-based geopolymer," Journal of Materials Science 49(6), 2548-2558. DOI: 10.1007/s10853-013-7950-0

Chen, W., Wu, C., Yu, H., Chen, Y., and Zheng, S. (2017). "Effect of calcined MgO-rich byproduct from the extraction of $\mathrm{Li}_{2} \mathrm{CO}_{3}$ on the performance of magnesium phosphate cement," Journal of Advanced Concrete Technology 15(12), 749-759. DOI: $10.3151 /$ jact.15.749

Chen, X-F., Kou, S-C., and Xing, F. (2019). "Effect of agriculture and construction wastes on the properties of magnesium oxychloride cement mortar with tourmaline powder," Materials 12(1), 115. DOI: 10.3390/ma12010115

Chennouf, N., Agoudjil, B., Alioua, T., Boudenne, A., and Benzarti, K. (2019). "Experimental investigation on hygrothermal performance of a bio-based wall made of cement mortar filled with date palm fibers," Energy and buildings 202, 109413. DOI: 10.1016/j.enbuild.2019.109413

Chi, H., and Englund, K. R. (2014). "Interfacial properties of magnesium phosphate ceramics and sugar maple (Acer saccharum)," Holzforschung 68(5), 575-582. DOI: 10.1515/hf-2013-0113

Cicala, G., Cristaldi, G., Recca, G., and Latteri, A. (2010). "Composites based on natural fibre fabrics," in: Woven Fabric Engineering, P. Dubrovski, (ed.), InTech, London, UK. pp. 317-342. DOI: 10.5772/10465

Cizer, Ö., Van Balen, K., and Van Gemert, D. (2010). "Competition between hydration and carbonation in hydraulic lime and lime-pozzolana mortars," Advanced Materials Research 133-134, 241-246. DOI: 10.4028/www.scientific.net/AMR.133-134.241

Coudert, L., Blais, J.-F., and Mercier, G. (2013). "Remediation processes for wood treated with organic and/or inorganic preservatives," in: Handbook of Recycled Concrete and Demolition Waste, F. Pacheco-Torgal, V.W.Y. Tam, J.A. Labrincha, Y. Ding, and J. de Brito (eds.), Woodhead Publishing Limited, 80 High Street, Sawston, Cambridge CB22 3HJ, UK. pp. 526-554. DOI: 10.1533/9780857096906.4.526

Correia, E. A. S., Torres, S. M., de Oliveira, A., Marcio, E., Gomes, K. C., Barbosa, N. P., and de Barros, S. (2013). "Mechanical performance of natural fibers reinforced geopolymer composites," Materials Science Forum 758, 139-145.

DOI: $10.4028 /$ www.scientific.net/msf.758.139 
Covill, A., Hyatt, N. C., Hill, J., and Collier, N. C. (2011). "Development of magnesium phosphate cement for encapsulation of radioactive waste," Advances in Applied Ceramics 110(3), 151-156. DOI: 10.1179/1743676110Y.0000000008

Dai, S. B., Wang, J. H., Hu, Y., and Zhang, D-B. (2010). "Lime-based materials and practices for surface refitting of cultural heritage," Advanced Materials Research 133-134, 1241-1246. DOI: 10.4028/www.scientific.net/amr.133-134.1241

Davidovits, J. (2013). Geopolymer Cement. A Review, Technical Paper \#21, Geopolymer Institute Library. www.geopolymer.org. 11p. Available from: https://www.researchgate.net/publication/306946529_Geopolymer_Cement_a_review _2013 [accessed December 20 2020].

Davidovits, J. (2017). "Geopolymers based on natural and synthetic metakaolin - A critical review," in: Proceedings of the $41^{\text {st }}$ International Conference on Advanced Ceramics and Composites, Daytona Beach, Florida, pp. 201-214. DOI: 10.1002/9781119474746

Di Bella, G., Fiore, V., Galtieri, G., Borsellino, C., and Valenza, A. (2014). "Effects of natural fibres reinforcement in lime plasters (kenaf and sisal vs. polypropylene)," Construction and Building Materials 58, 159-165. DOI:

10.1016/j.conbuildmat.2014.02.026

Ding, Z., and Li, Z. (2005a). "Study of high early strength cement based on fly ash, magnesia and phosphate," Materials Technology 20(3), 136-141.

DOI: $10.1080 / 10667857.2005 .11753125$

Ding, Z., and Li, Z. (2005b). "Effect of aggregates and water contents on the properties of magnesium phospho-silicate cement," Cement and Concrete Composites 27(1), 1118. DOI: 10.1016/j.cemconcomp.2004.03.003

Donahue, P. K., and Aro, M. D. (2010). "Durable phosphate-bonded natural fiber composite products," 24(2), 215-219. DOI: 10.1016/j.conbuildmat.2007.05.015

Duan, P., Yan, C., Zhou, W., and Luo, W. (2016). "Fresh properties, mechanical strength and microstructure of fly ash geopolymer paste reinforced with sawdust," Construction and Building Materials 111, 600-610. DOI:

10.1016/j.conbuildmat.2016.02.091

Elfordy, S., Lucas, F., Tancret, F., Scudeller, Y., and Goudet, L. (2008). "Mechanical and thermal properties of lime and hemp concrete ("hempcrete") manufactured by a projection process," Construction and Building Materials 22(10), 2116-2123. DOI: 10.1016/j.conbuildmat.2007.07.016

Evrard, A., and De Herde, A. (2010). "Hygrothermal performance of lime-hemp wall assemblies," Journal of Building Physics 34(1), 5-25. DOI: 10.1177/1744259109355730

Fan, S., and Chen, B. (2015). "Experimental research of water stability of magnesium alumina phosphate cement mortar," Construction and Building Materials 94, 164171. DOI: 10.1016/j.conbuildmat.2015.06.050

Fic, S., Brzyski, P., and Szeląg, M. (2013). "Composite based on foam lime mortar with flax fibers for use in the building industry," Ecological Chemistry and Engineering. A 20(7-8), 899-907. DOI: 10.2428/ecea.2013.20(07)084

Frybort, S., Mauritz, R. Teischinger, A., and Müller, U. (2008). "Cement bonded composites - A mechanical review," BioResources 3(2), 602-626.

Ghavami, K., and Savastano Junior, H. (2017). "Introductory remarks-The nonconventional materials (NOCMAT) for sustainable infrastructure regeneration in $21^{\text {st }}$ century," in: Sustainable and Nonconventional Construction Materials using 
Inorganic Bonded Fiber Composites, H. Savastano Jnr, J. Fiorelli, and S. F. dos Santos (eds.), Woodhead Publishing, United Kingdom. pp. xix-xxviii. DOI: 10.1016/B978-0-08-102001-2.00024-3

Glé, P., Gourdon, E., and Arnaud, L. (2011). "Acoustical properties of materials made of vegetable particles with several scales of porosity," Applied Acoustics 72(5), 249259. DOI: 10.1016/j.apacoust.2010.11.003

Gomes, C. E. M., and Camarini, G. (2014). "Magnesium oxysulfate fiber cement," Key Engineering Materials 600, 308-318. DOI: 10.4028/www.scientific.net/KEM.600.308

Guo, Y., Zhang, Y., Soe, K., and Pulham, M. (2018). "Recent development in magnesium oxychloride cement," Structural Concrete 1-11. DOI: 10.1002/suco.201800077

Hall, D.A., Stevens, R., and El-Jazairi, B. (2001). "The effect of retarders on the microstructure and mechanical properties of magnesia-phosphate cement mortar," Cement and Concrete Research 31(3), 455-465.DOI:10.1016/s0008-8846(00)00501-9

Heah, C. Y., Kamarudin, H., Mustafa Al Bakri, A. M., Binhussain, M., Luqman, M., Nizar, I. K., Ruzaidi, C. M., and Liew, Y. M. (2011). "Effect of curing profile on kaolin-based geopolymers," Physics Procedia 22, 305-311. DOI: 10.1016/j.phpro.2011.11.048

Hirst, E. A. J., Walker, P., Paine, K., and Yates T. (2010). "Characterisation of low density hemp-lime composite building materials under compression loading," in: The $2^{\text {nd }}$ International Conference on Sustainable Construction Materials and Technologies, J. Zachar, P. Claisse, T. R. Naik, and E. Ganjian (eds.), Università Politecnica delle Marche, Ancona, Italy, $28^{\text {th }}-30^{\text {th }}$ June, 2010. https://www.researchgate.net/publication/268415710_Characterisation_of_Low_Dens ity _Hemp-Lime_Composite_Building_Materials_under_Compression_Loading [accessed November 05, 2020].

Irle, M, Barbu, M. C., Reh, R., Bergland, L., and Rowell, R. M. (2013). "Chapter 10: Wood composites," in: Handbook of Wood Chemistry and Wood Composites, R. M. Rowel (ed.), $2^{\text {nd }}$ Ed., CRC Press, London. pp. 321-411.

Jeong, S. Y., and Wagh, A. S. (2003). "Cementing the gap between ceramics, cement, and polymers," Materials Technology Advanced Performance Materials 18(3), $162-$ 168. DOI: $10.1080 / 10667857.2003 .11753035$

Jiang, Z., Zhang, L., Geng, T., Lai, Y., Zheng, W., and Huang, M. (2020a). "Study on the compressive properties of magnesium phosphate cement mixing with eco-friendly coir fiber considering fiber length," Materials 13(14), 3194. DOI: 10.3390/ma13143194

Jiang, C., Wang, A., Bao, X., Ni, T., and Ling, J. (2020b). “A review on geopolymer in potential coating application: Materials, preparation and basic properties," Journal of Building Engineering 32, 101734. DOI: 10.1016/j.jobe.2020.101734

Jin, F., and Al-Tabbaa, A. (2014). "Strength and hydration products of reactive MgOsilica pastes," Cement and Concrete Composites 52, 27-33. DOI: 10.1016/j.cemconcomp.2014.04.003

Jin, S., Li, K., Li, J., and Chen, H. (2017). "A low-cost, formaldehyde-free and high flame retardancy wood adhesive from inorganic adhesives: Properties and performance," Polymers 9(12), 513. DOI: 10.3390/polym9100513

Kang, S.-H., Kwon, Y.-H., and Moon, J. (2019). "Quantitative analysis of $\mathrm{CO}_{2}$ uptake and mechanical properties of air lime-based materials," Energies 12(15), 2903. DOI: 10.3390/en12152903 
Karthikeyan, N., Sathishkumar, A., and Dennis, J. R. W. (2014). "Effects on setting, strength and water resistance of sorel cement on mixing fly ash as an additive," International Journal of Mechanical Engineering and Robotics Research 3(2), 251256. http://www.ijmerr.com/v3n2/ijmerr_v3n2_31.pdf [accessed December 08, 2020]

Kielè, A., Vaičiukynienė, D., Tamošaitis, G., Pupeikis, D., and Bistrickaitė, R. (2020). "Wood shavings and alkali-activated slag bio-composite," European Journal of Wood and Wood Products 78(3), 513-522. DOI: 10.1007/s00107-020-01516-X

Kinnane, O., McGranaghan, G., Walker, R., Pavia, S., Byrne, G., and Robinson, A. (2015). "Experimental investigation of thermal inertia properties in hemp-lime concrete walls," in: Proceedings of the $10^{\text {th }}$ Conference on Advanced Building Skins, Bern, Switzerland, pp. 942-949.

https://pureadmin.qub.ac.uk/ws/files/17262817/D.2_6_Kinnane_et_al._ABS_Final.pd f [accessed November 05, 2020]

Korniejenko, K., Frączek, E., Pytlak, E., and Adamski, M. (2016). "Mechanical properties of geopolymer composites reinforced with natural fibers," Procedia Engineering 151, 388-393. DOI: 10.1016/j.proeng.2016.07.395

Korniejenko, K., Lin, W-T., and Šimonová, H. (2020a). "Mechanical properties of short polymer fiber-reinforced geopolymer composites," Journal of Composites Science 4(3), 128. DOI: 10.3390/jcs4030128

Korniejenko, K., Łach, M., Dogan-Saglamtimur, N., Furtos, G., and Mikuła, J. (2020b). "The overview of mechanical properties of short natural fiber reinforced geopolymer composites," Environmental Research and Technology 3(1), 28-39.

DOI: $10.35208 /$ ert.671713

Kriven, W. M., Wang, J., Zhou, Y., Gyekenyesi, A. L., Kirihara, S., and Widjaja, S. (2013). "Green composite: Sodium-based geopolymer reinforced with chemically extracted corn husk fibers," in: Developments in Strategic Materials and Computational Design [Ceramic Engineering and Science Proceedings], W. M. Kriven, J. Wang, Y. Zhou, and A. L. Gyekenyesi (eds.), pp. 123-133. DOI: 10.1002/9781118807743.ch11

Lahoti, M., Wijaya, S. F., Tan, K. H., and Yang, E.-H. (2020). "Tailoring sodium-based fly ash geopolymers with variegated thermal performance," Cement and Concrete Composites 107, article no. 103507. DOI: 10.1016/j.cemconcomp.2019.103507

Laufenberg, T. L., and Aro, M. (2004). "Phosphate-bonded ceramic-wood composites: RandD project overview and invitation to participate," in: The Ninth International Conference on Inorganic-Bonded Composite Materials Conference, University of Idaho, October 10-13, 2004, Vancouver, British Columbia, Canada. 12 p. https://www.fpl.fs.fed.us/documnts/pdf2004/fpl_2004_laufenberg001.pdf [accessed November 10, 2020]

Lemougna, P. N., Adediran, A., Yliniemi, J., Ismailov, A., Levanen, E., Tanskanen, P., Kinnunen, P., Roning, J., and Illikainen, M. (2020). "Thermal stability of one-part metakaolin geopolymer composites containing high volume of spodumene tailings and glass wool," Cement and Concrete Composites 114, 103792.

DOI: 10.1016/j.cemconcomp.2020.103792

Li, C., Sun, H., and Li, L. (2010). "A review: The comparison between alkali-activated slag $(\mathrm{Si}+\mathrm{Ca})$ and metakaolin $(\mathrm{Si}+\mathrm{Al})$ cement," Cement and Concrete Research 40 (9), 1341-1349. DOI: 10.1016/j.cemconres.2010.03.020 
Li, Y., and Chen, B. (2013). "Factors that affect the properties of magnesium phosphate cement," Construction and Building Materials 47, 977-983.

DOI: 10.1016/j.conbuildmat.2013.05.103

Li, D. X., and Feng, C. H. (2010). "Study on modification of the magnesium phosphate cement-based material by fly ash," Advanced Materials Research 150-151, 16551661. DOI: 10.4028/www.scientific.net/AMR.150-151.1655

Li, Y., Li, Y., Shi, T., and Li, J. (2015). "Experimental study on mechanical properties and fracture toughness of magnesium phosphate cement," Construction and Building Materials 96, 346-352. DOI: 10.1016/j.conbuildmat.2015.08.012

Li, Y., Shi, T., and Li, J. (2016). "Effects of fly ash and quartz sand on water-resistance and salt-resistance of magnesium phosphate cement," Construction and Building Materials 105, 384-390. DOI: 10.1016/j.conbuildmat.2015.12.154

Li, S.-Q., Tian, Y.-L., Xu, C.-W., Wang, J.-H., Sun, S.-B., and Qi, H. (2017). "Effect of EVA emulsion on the properties of corn stalk magnesium oxychloride cement composites," Applied Mechanics and Materials 863, 71-77. DOI: 10.4028/www.scientific.net/amm.863.71

Li, K., Wang, Y., Yao, N., and Zhang, A. (2020). "Recent progress of magnesium oxychloride cement: manufacture, curing, structure and performance," Construction and Building Materials 255, 119381. DOI: 10.1016/j.conbuildmat.2020.119381

Li, Z., Yu, Y., Li, J., Wang, Y., and Liu, H. (2003). "Experimental study on urban refuse/magnesium oxychloride cement compound floor tile," Cement and Concrete Research 33(10), 1663-1668. DOI: 10.1016/s0008-8846(03)00136-4

Liang, J., Zhao, F., Guo, J., and Yao, K. (2019a). "Properties and reaction mechanisms of magnesium phosphate cement mixed with ferroaluminate cement," Materials 12, 2561. DOI: $10.3390 / \mathrm{ma} 12162561$

Liang, G., Zhu, H., Zhang, Z., and Wu, Q. (2019b). "Effect of rice husk ash addition on the compressive strength and thermal stability of metakaolin based geopolymer," Construction and Building Materials 222, 872-881.

DOI: 10.1016/j.conbuildmat.2019.06.200

Liao, W., Ma, H., Sun, H., Huang, Y., and Wang, Y. (2017). "Potential large-volume beneficial use of low-grade fly ash in magnesia-phosphate cement based materials," Fuel. 209, 490-497. DOI: 10.1016/j.fuel.2017.08.028

Liu, N., and Chen, B. (2015). "Experimental investigation concrete using magnesium phosphate cement, fly ash, and rape stalk," Journal of Materials in Civil Engineering 04015163. DOI: 10.1061/(ASCE)MT.1943-5533.0001459

Liu, N., and Chen, B. (2016). "Experimental research on magnesium phosphate cement containing alumina," Construction and Building Materials 121, 354-360.

DOI: 10.1016/j.conbuildmat.2016.06.010

Lorca, P., Calabuig, R., Benlloch, J., Soriano, L., and Payá, J. (2014). "Microconcrete with partial replacement of portland cement by fly ash and hydrated lime addition," Materials and Design 64, 535-541. DOI: 10.1016/j.matdes.2014.08.022

Lothenbach, B., Nied, D., L'Hôpital, E., Achiedo, G., and Dauzères, A. (2015). "Magnesium and calcium silicate hydrates," Cement and Concrete Research 77, 6068. DOI: 10.1016/j.cemconres.2015.06.007

Lu, X., and Chen, B. (2016). "Experimental study of magnesium phosphate cement modified by metakaolin," Construction and Building Materials 123, 719-726.

DOI: 10.1016/j.conbuildmat.2016.07.092 
Malenab, R., Ngo, J., and Promentilla, M. (2017). "Chemical treatment of waste abaca for natural fiber-reinforced geopolymer composite," Materials. 10(6), 579. DOI: $10.3390 / \mathrm{ma10060579}$

Martínez-García, C., González-Fonteboa, B., Carro-López, D., and Martínez-Abella, F. (2019). "Impact of mussel shell aggregates on air lime mortars. pore structure and carbonation," Journal of Cleaner Production 215, 650-668. DOI:

10.1016/j.jclepro.2019.01.121

Mármol, G., and Savastano Jr, H. (2017). "Study of the degradation of non-conventional $\mathrm{MgO}-\mathrm{SiO}_{2}$ cement reinforced with lignocellulosic fibers," Cement and Concrete Composites 80, 258-267. DOI: 10.1016/j.cemconcomp.2017.03.015

Miller, S. A., John, V. M., Pacca, S.A., and Horvath, A. (2017). "Carbon dioxide reduction potential in the global cement industry by 2050," Cement and Concrete Research 114(2018), 115-124. DOI: 10.1016/j.cemconres.2017.08.026

Mohammed, L., Ansari, M. N. M., Pua, G., Jawaid, M., and Islam, M. S. (2015). “A review on natural fiber reinforced polymer composite and its applications," International Journal of Polymer Science 2015, 1-15. DOI: 10.1155/2015/243947

Mo, L., Zhang, F., Panesar, D. K., and Deng, M. (2017). "Development of low-carbon cementitious materials via carbonating portland cement - fly ash - magnesia blends under various curing scenarios: A comparative study," Journal of Cleaner Production 163, 252-261. DOI: 10.1016/j.jclepro.2016.01.066

Montle, J. F., and Mayhan, K. G. (1974). "The role of magnesium oxychloride as a fireresistive material," Fire Technology 10(3), 201-210. DOI: 10.1007/bf02588845

Moslemi, A. A., and Begum, S. (2017). "Wood composites: Mineral-bonded," Reference Module in Materials Science and Materials Engineering 1-4. DOI: 10.1016/b978-012-803581-8.02378-x

Murphy, F., Pavia, S., and Walker, R. (2010). "An assessment of some physical properties of lime-hemp concrete," in: Proceedings of the Concrete Research Ireland (CRI) and Bridge Research Ireland (BRI) symposium, University College Cork, Ireland, Ni Nuallain, Walsh, West, Cannon, Caprani, McCabe (eds.). pp. 431-438. https://citeseerx.ist.psu.edu/viewdoc/download?doi=10.1.1.1001.3069andrep=rep1an dtype $=$ pdf (accessed November 03, 2020)

Nagavally, R. R. (2016). "Composite materials - History, types, fabrication techniques, advantages, and applications," International Journal of Advances in Science Engineering and Technology 4(2), 87-92.

Nayaka, R. R., Alengaram, U. J., Jumaat, M. Z., Yusoff, S. B., and Alnahhal, M. F. (2018). "High volume cement replacement by environmental friendly industrial byproduct palm oil clinker powder in cement-lime masonry mortar," Journal of Cleaner Production 190, 272-284.

Nozahic, V., Amziane, S., Torrent, G., Saïdi, K., and De Baynast, H. (2012). "Design of green concrete made of plant-derived aggregates and a pumice-lime binder," Cement and Concrete Composites 34(2), 231-241. DOI: 10.1016/j.cemconcomp.2011.09.002

Page, J., Sonebi, M., and Amziane, S. (2017). "Design and multi-physical properties of a new hybrid hemp-flax composite material," Construction and Building Materials 139, 502-512. DOI: 10.1016/j.conbuildmat.2016.12.037

Park, J. H., Kang, Y., Lee, J., Chang, S. J., Wi, S., and Kim, S. (2019). "Development of wood-lime boards as building materials improving thermal and moisture performance based on hygrothermal behavior evaluation," Construction and Building Materials 204, 576-585. DOI: 10.1016/j.conbuildmat.2019.01.139 
Patel, R., and Joshi, R. (2016). "Analysis of development of porous fly ash-based geopolymer with low thermal conductivity," International Advanced Research Journal in Science, Engineering and Technology 3(12), 171-178. Available from https://www.iarjset.com/upload/2016/december-16/IARJSET\%2033.pdf [accessed January 22 2021].

Patil, A. A., Chore, H. S., and Dode, P. A. (2014). "Effect of curing condition on strength of geopolymer concrete," Advances in Concrete Construction 2(1), 29-37.

DOI: 10.12989/acc.2014.2.1.029

Pavlík, V., and Užáková, M. (2016). "Effect of curing conditions on the properties of lime, lime-metakaolin and lime-zeolite mortars," Construction and Building Materials 102, 14-25. DOI: 10.1016/j.conbuildmat.2015.10.128

Payá, J., Monzo, J., Borachero, M. V., Soriano, L., Akasaki, J. L., and Tashima, M. M. (2017). "New inorganic binders containing ashes from agricultural wastes," in: Sustainable and Nonconventional Construction Materials using Inorganic Bonded Fiber Composites, H. Savastano Jnr, J. Fiorelli, and S.F. dos Santos (eds.), Woodhead Publishing, United Kingdom, pp. xix-xxviii. DOI: 10.1016/B978-0-08-1020012.00006-1

Péra, J., and Ambroise, J. (1998). "Fiber-reinforced magnesia-phosphate cement composites for rapid repair," Cement and Concrete Composites 20(1), 31-39. DOI: 10.1016/s0958-9465(97)00067-x

Pochwała, S., Makiola, D., Anweiler, S., and Böhm, M. (2020). "The heat conductivity properties of hemp-lime composite material used in single-family buildings," Materials 13(4), 1011. DOI: 10.3390/ma13041011

Poletanovic, B., Dragas, J., Ignjatovic, I., Komljenovic, M., and Merta, I. (2020). "Physical and mechanical properties of hemp fiber reinforced alkali-activated fly ash and fly ash / slag mortars," Construction and Building Materials 259, 119677. DOI: 10.1016/J.CONBUILDMAT.2020.119677

Puertas, F., and Fernández-Jiménez, A. (2003). "Mineralogical and microstructural characterisation of alkali-activated fly ash/slag pastes," Cement and Concrete Composites 25(3), 287-292. DOI: 10.1016/S0958-9465(02)00059-8

Qin, J., Qian, J., Li, Z., You, C., Dai, X., Yue, Y., and Fan, Y. (2018a). "Mechanical properties of basalt fiber reinforced magnesium phosphate cement composites," Construction and Building Materials 188, 946-955. DOI:

10.1016/j.conbuildmat.2018.08.044

Qin, L., Gao, X., and Chen, T. (2018b). "Recycling of raw rice husk to manufacture magnesium oxysulfate cement based lightweight building materials," Journal of Cleaner Production 191, 220-232. DOI: 10.1016/j.jclepro.2018.04.238

Rahim, M., Douzane, O., Tran Le, A.D., Promis, G., Laidoudi, B., Crigny, A., Dupre, B., and Langlet, T. (2015). "Characterization of flax lime and hemp lime concretes: Hygric properties and moisture buffer capacity," Energy and Buildings 88, 91-99. DOI: 10.1016/j.enbuild.2014.11.043

Rajak, D. K., Pagar, D. D., Menezes, P. L., and Linul, E. (2019). "Fiber-reinforced polymer composites: Manufacturing, properties, and applications," Polymers 11, 1667. DOI: $10.3390 /$ polym 11101667

Rashad, A. M. (2013). "A comprehensive overview about the influence of different additives on the properties of alkali-activated slag - A guide for civil engineer," Construction and Building Materials 47, 29-55. DOI:

10.1016/j.conbuildmat.2013.04.011 
RILEM TC 224-AAM (2014). Alkali Activated Materials, State-of-the-Art Report, J. L. Provis, J. S. J. Van Deventer (eds.), Springer, Dordrecht. 395p.

Sarmin, S. N., Welling J., Krause, A., and Shalbafan, A. (2014). "Investigating the possibility of geopolymer to produce inorganic-bonded wood composites for multifunctional construction material - A review," BioResources 9, 7941-7950. DOI: 10.15376/biores.9.4.7941-7950

Sarmin, S. N. (2016). "The influence of different wood aggregates on the properties of geopolymer composites," Key Engineering Materials 723, 74-79.

DOI: $10.4028 /$ www.scientific.net/kem.723.74

Shalbafan, A., Nadali, A., and Thoemen, H. (2020). "A multifunctional mineral binder for plywood production: The effect of manufacturing parameters on bonding quality," Materials 13, 2360. DOI: 10.3390/ma13102360

Shalbafan, A., and Thoemen, H. (2020). "Geopolymer-bonded laminated veneer lumber as environmentally friendly and formaldehyde-free product: Effect of various additives on geopolymer binder features," Applied Sciences 10(2), 593. DOI: 10.3390/app10020593

Shalbafan, A., Welling, J., and Hasch, J. (2016). "Geopolymers as potential new binder class for the wood based composite industry," Holzforschung 70(8), 1-7. DOI: 10.1515/hf-2015-0206

Shao, M., Li, L., Chen, W., and Liu, J. (2018). "Investigation and modification of two kinds of Chinese traditional lime in cultural building relics," Journal of Cultural Heritage 36, 118-127. DOI: 10.1016/j.culher.2018.02.018

Shi, Y., Chen, B., and Ahmad, M. R. (2019). "Effects of alumina as an effective constituent of metakaolin on properties of magnesium phosphate cement," Journal of Materials in Civil Engineering 31(8), 04019147. DOI: 10.1061/(ASCE)MT.19435533.0002779

Silva, G., Kim, S., Aguilar, R., and Nakamatsu, J. (2019). "Natural fibers as reinforcement additives for geopolymers - A review of potential eco-friendly applications to the construction industry," Sustainable Materials and Technologies 23, e00132. DOI: 10.1016/j.susmat. 2019.e00132

Silva, G., Kim, S., Bertolotti, B., Nakamatsu, J., and Aguilar, R. (2020). "Optimization of a reinforced geopolymer composite using natural fibers and construction wastes," Construction and Building Materials 258, 119697. DOI:

10.1016/j.conbuildmat.2020.119697

Soltan, D. G., das Neves, P., Olvera, A., Savastano Junior, H., and Li, V. C. (2017). "Introducing a curauá fiber reinforced cement-based composite with strain-hardening behavior," Industrial Crops and Products 103, 1-12. DOI:

10.1016/j.indcrop.2017.03.016

Sorell, C. A., and Armstrong, C. R. (1976). "Reaction and equilibria in magnesium oxychloride cement," Journal of the American Ceramic Society 59(1-2), 51-54. DOI: 10.1111/j.1151-2916.1976.tb09387.x

Stark, N. M., Cai, Z., and Carll, C. (2010). "Chapter 11: Wood-based composite materials panel products, glued-laminated timber, structural composite lumber, and woodnonwood composite materials," in: Wood Handbook: Wood as an Engineering Material: Centennial (ed.) General Technical Report FPL, GTR-190. USDA Forest Service, Forest Products Laboratory, Madison, WI, pp. 11.1-11.28

Tan, J., Lu, W., Huang, Y., Wei, S., Xuan, X., Liu, L., and Zheng, G. (2019). "Preliminary study on compatibility of metakaolin-based geopolymer paste with plant 
fibers," Construction and Building Materials 225, 772-775. DOI:

10.1016/j.conbuildmat.2019.07.142

Tan, Y., Yu, H., Li, Y., Bi, W., and Yao, X. (2016). "The effect of slag on the properties of magnesium potassium phosphate cement," Construction and Building Materials 126, 313-320. DOI: 10.1016/j.conbuildmat.2016.09.041

van Jaarsveld, J. G. S., van Deventer, J. S. J., and Lukey, G. C. (2002). "The effect of composition and temperature on the properties of fly ash- and kaolinite-based geopolymers," Chemical Engineering Journal 89(1-3), 63-73. DOI: 10.1016/s13858947(02)00025-6

Van Nguyen, C., and Mangat, P. S. (2020). "Properties of rice straw reinforced alkali activated cementitious composites," Construction and Building Materials 261, 120536. DOI: 10.1016/j.conbuildmat.2020.120536

Veiga, R. (2017). "Air lime mortars: What else do we need to know to apply them in conservation and rehabilitation interventions? A Review," Construction and Building Materials 157, 132-140. DOI: 10.1016/j.conbuildmat.2017.09.080

Wagh, A., Jeong, S. Y., and Singh, D. (1997). "High strength phosphate cement using industrial byproduct ashes," in: Proceedings of the First Engineering Foundation Conference on High Strength Concrete, American Society of Civil Engineers, $13^{\text {th }}$ $18^{\text {th }}$ July, 1997 in Kona, Hawaii, A. Azizinamini, D. Darwin, and C. French (eds), pp. 542-553.

https://www.researchgate.net/profile/Arun_Wagh/publication/237759513_High_stren gth_phosphate_cement_using_industrial_byproduct_ashes/links/5681451608ae051f9 aec387a/High-strength-phosphate-cement-using-industrial-byproduct-ashes.pdf [accessed November 20, 2020]

Wagh, A. S., Singh, D., and Jeong, S. Y. (2001). "Chemically bonded phosphate ceramics for stabilization and solidification of mixed wastes," in: Hazardous and Radioactive Waste Treatment Technologies Handbook, C. H. Oh (ed.), CRC Press, Boca Raton, FL, USA, pp. 6.3.1-6.3.18.

Wagh, A. S. (2016). Chemically Bonded Phosphate Ceramics: Twenty First Century Materials with Diverse Applications, $2^{\text {nd }}$ Ed., Elsevier Ltd., The Boulevard, Langford Lane, Kidlington, Oxford OX5 1GB, UK, 400p. ISBN: 978-0-08-100380-0

Walker, R., and Pavia, S. (2010). "Behaviour and properties of lime-pozzolan pastes," in: Proceedings of the $8^{\text {th }}$ International Masonry Conference, Dresden, Germany. pp. 353-362.

http://www.tara.tcd.ie/bitstream/handle/2262/57401/Behaviour\%20and\%20Properties $\% 20$ of\%20Lime-Pozzolan\%20Pastes.pdf?sequence=1 andisAllowed=y [accessed November 05, 2020]

Walker, R., and Pavía, S. (2014). "Moisture transfer and thermal properties of hemp-lime concretes," Construction and Building Materials 64, 270-276.

DOI: 10.1016/j.conbuildmat.2014.04.081

Walker, R., Pavia, S., and Mitchell, R. (2014). "Mechanical properties and durability of hemp-lime concretes," Construction and Building Materials 61, 340-348.

DOI: 10.1016/j.conbuildmat.2014.02.065

Walling, S. A., and Provis, J. L. (2016). "Magnesia-based cement: A journey of 150 years, and cement for the future?," Chemical Reviews 116(7), 4170-4204.

DOI: $10.1021 /$ acs.chemrev.5b00463 
Waldmann, D., and Thapa, V. B. (2018). "A short review on alkali-activated binders and geopolymer binders," Vielfalt im Massivbau-Festschrift zum 65. Geburtstag von Prof. Dr. Ing. Jürgen Schnell, 576-591. http://hdl.handle.net/10993/35284

Wang, L., Yu, I. K. M., Tsang, D. C. W., Li, S., Li, J-S., Poon, C. S., Wang, Y.-S., and Dai, J.-G. (2017). "Transforming wood waste into water-resistant magnesiaphosphate cement particleboard modified by alumina and red mud," Journal of Cleaner Production 168, 452-462. DOI: 10.1016/j.jclepro.2017.09.038

Wang, L., Yu, I. K. M., Tsang, D. C. W., Yu, K., Li, S. Sun Poon, C., and Dai, J. (2018). "Upcycling wood waste into fibre-reinforced magnesium phosphate cement particleboards," Construction and Building Materials 159, 54-63.

DOI: 10.1016/j.conbuildmat.2017.10.107

Wang, R., Qin, L., and Gao, X. (2020). "Mechanical strength and water resistance of magnesium oxysulfate cement based lightweight materials," Cement and Concrete Composites 109, 103554. DOI: 10.1016/j.cemconcomp.2020.103554

Wei, Y., Song, C., Chen, B., and Ahmad, M. R. (2019). "Experimental investigation on two new corn stalk biocomposites based on magnesium phosphate cement and ordinary portland cement," Construction and Building Materials 224, 700-710. DOI: 10.1016/j.conbuildmat.2019.07.100

Wu, C., Chen, W., Zhang, H., Yu, H., Zhang, W., Jiang, N., and Liu, L. (2017). "The hydration mechanism and performance of modified magnesium oxysulfate cement by tartaric acid," Construction and Building Materials 144, 516-524.

DOI: 10.1016/j.conbuildmat.2017.03.222

Yang, N., Shi, C., Yang, J., and Chang, Y. (2014). "Research progresses in magnesium phosphate cement-based materials," Journal of Materials in Civil Engineering 26(10), 04014071. DOI: 10.1061/(asce)mt.1943-5533.0000971

Yaprak, H., Alnkaa, A., Memis, S., and Kaplan, G. (2019). "Effects of different curing conditions on the properties of geopolymeric mortar," MOJ Civil Engineering 5(1), 45-50. DOI: 10.15406/mojce.2019.05.00148

Ye, H., Zhang, Y., Yu, Z., and Mu, J. (2018). "Effects of cellulose, hemicellulose, and lignin on the morphology and mechanical properties of metakaolin-based geopolymer," Construction and Building Materials 173, 10-16. DOI: 10.1016/j.conbuildmat.2018.04.028

You, C., Qian, J., Qin, J., Wang, H., Wang, Q., and Ye, Z. (2015). "Effect of early hydration temperature on hydration product and strength development of magnesium phosphate cement (MPC)," Cement and Concrete Research 78, 179-189.

DOI: 10.1016/j.cemconres.2015.07.005

Zhang, T., Vandeperre, L. J., and Cheeseman, C. R. (2014). "Formation of magnesium silicate hydrate (MSH) cement pastes using sodium hexametaphosphate," Cement and Concrete Research 65, 8-14. DOI: 10.1016/j.cemconres.2014.07.001

Zhang, L., Jiang, Z., Wu, H., Zhang, W., Lai, Y., Zheng, W., and Li, J. (2020a). "Flexural properties of renewable coir fiber reinforced magnesium phosphate cement, considering fiber length," Materials 13(17), 3692. DOI: 10.3390/ma13173692

Zhang, L., Jiang, Z., Zhang, W., Peng, S., and Chen, P. (2020b). "Flexural properties and microstructure mechanisms of renewable coir-fiber-reinforced magnesium phosphate cement-based composite considering curing ages," Polymers 12(11), 2556. DOI: 10.3390/polym 12112556

Zheng, D. -D., Ji, T., Wang, C. -Q., Sun, C. -J., Lin, X. -J., and Hossain, K. M. A. (2016). "Effect of the combination of fly ash and silica fume on water resistance of 
magnesium-potassium phosphate cement," Construction and Building Materials 106, 415-421. DOI: 10.1016/j.conbuildmat.2015.12.085

Zhou, X., and Li, Z. (2012). "Light-weight wood-magnesium oxychloride cement composite building products made by extrusion," Construction and Building Materials 27(1), 382-389. DOI: 10.1016/j.conbuildmat.2011.07.033

Zhu, J., Zheng, W., Sneed, L., Huang, Y., and Xu, C. (2019). "Mechanical properties of plant fibers reinforced alkali-activated slag cementitious material at high temperature," Annales de Chimie-Science des Matériaux 43(4), 249-255. DOI: 10.18280/acsm.430408

Živica, V. (2007). "Effects of type and dosage of alkaline activator and temperature on the properties of alkali-activated slag mixtures," Construction and Building Materials 21(7), 1463-1469. DOI: 10.1016/j.conbuildmat.2006.07.002

Article submitted: March 2, 2021; Peer review completed: April 7, 2021; Revised version received and accepted: April 20, 2021; Published: April 22, 2021.

DOI: 10.15376/biores.16.2. Emmanuel 